\title{
Medicago truncatula Gaertn. as a model for understanding the mechanism of growth promotion by bacteria from rhizosphere and nodules of alfalfa
}

\author{
Anna Kisiel $^{1} \cdot$ Ewa Kępczyńska' $^{1}$
}

Received: 25 August 2015/Accepted: 14 January 2016/Published online: 10 February 2016

(C) The Author(s) 2016. This article is published with open access at Springerlink.com

\begin{abstract}
Main conclusion The present study showed all the $\mathbf{1 6}$ strains isolated and identified from the alfalfa rhizosphere and nodules, and registered in GenBank, to be good candidates for targeted use in studies addressing the rather weak known mechanism of plant growth promotion, including that of Medicago truncatula, a molecular crop model.

Based on physiological, biochemical and molecular analysis, the 16 isolates obtained were ascribed to the following five families: Bacillaceae, Rhizobiaceae, Xantomonadaceae, Enterobacteriaceae and Pseudomonadaceae, within which 9 genera and 16 species were identified. All these bacteria were found to significantly enhance fresh and dry weight of root, shoots and whole 5 -week-old seedlings. The bacteria were capable of the in vitro use of tryptophan to produce indolic compounds at various concentrations. The ability of almost all the strains to enhance growth of seedlings and individual roots was positively correlated with the production of the indolic compounds $(r=0.69 ; \quad P=0.0001)$, but not with the 1-aminocyclopropane-1-carboxylate deaminase (ACCD) activity (no correlation). For some strains, it was difficult to conclude whether the growth promotion was related to the production of indolic compounds or to the ACCD activity. It is likely that promotion of $M$.
\end{abstract}

Electronic supplementary material The online version of this article (doi:10.1007/s00425-016-2469-7) contains supplementary material, which is available to authorized users.

Ewa Kępczyńska

ekepcz@univ.szczecin.pl

1 Department of Plant Biotechnology, Faculty of Biology, University of Szczecin, Wąska 13, 71-415 Szczecin, Poland truncatula root development involves also root interaction with pseudomonads, known to produce 2,4-diacetylphloroglucinol (DAPG), a secondary metabolite reported to alter the root architecture by interacting with an auxin-dependent signaling pathway. Inoculation of seedlings with Pseudomonas brassicacearum KK 5, a bacterium known for its lowest ability to produce indolic compounds, the highest ACCD activity and the presence of the phlD gene responsible for DAPG precursor synthesis, resulted in a substantial promotion of root development. Inoculation with the strain increased the endogenous IAA level in $M$. truncatula leaves after inoculation of 5-week-old seedlings. Three other strains examined in this study also increased the IAA level in the leaves upon inoculation. Moreover, several other factors such as mobilization of phosphorus and zinc to make them available to plants, iron sequestration by siderophore production and the ability to ammonia production also contributed substantially to the phytostimulatory biofertilizing potential of isolated strains. There is, thus, evidence that Medicago truncatula growth promotion by rhizobacteria involves more than one mechanism.

Keywords ACC deaminase - Bacteria identification . Growth promotion - Indole acetic acid (IAA) content . PGPR traits $\cdot$ PhlD gene detection
Abbreviations
ACC 1-Aminocyclopropane-1-carboxylate acid
ACCD 1-Aminocyclopropane-1-carboxylate deaminase
DAPG 2,4-Diacetylphloroglucinol
IAA Indole acetic acid
PGPR Plant growth promoting rhizobacteria 


\section{Introduction}

The family Fabaceae, called also Leguminosae, is the third largest family among angiosperms and second only to the Gramineae in their importance for humans (Graham and Vance 2003). The family's most commercially important species worldwide include the soybean (Glycine max), the garden pea (Pisum sativum), the peanut (Arachis hypogaea) and the alfalfa (Medicago sativa). Those plants are the most important source of protein and oil for humans and animals, and enrich the soil with nitrogen. They are also important as a fuelwood and with respect to carbon (C) sequestration (Abberton 2010). Among forage crops, cultivation of $M$. sativa covers the largest acreage worldwide and produces the largest profit. Furthermore, the alfalfa, one of the most important small legumes, is highly adaptable to different climatic and soil conditions, which facilitate its cultivation worldwide. Cultivation of alfalfa has, for many years, been known to bring benefits for the soil, e.g., structure improvement, protection against wind and water erosion, nitrogen and organic enrichment, and weed population reduction. The increasing concerns about a decline in soil organic matter content and fertility as well as the rising costs of energy and nitrogen fertilizers have renewed the interest in legumes.

Recently, the role of legumes and their contribution to both the sustainable intensification of agricultural production and the livelihoods of small-holder organic farmers in many parts of the world have featured on the research and economic agendas. Alfalfa is grown for hay, pasture, seed and-in some areas-as a major crop for the dehydration industry. It also finds its use in many medical formulae, and the available preparations such as alfalfa tonic and malt are known for their health benefits on account of a variety of bioactive natural products the alfalfa-based preparations contain (Gholami et al. 2014). The seed production in the temperate climate is limited mainly by the too short growing season due to the low temperature and insufficient sunlight resulting in delay of the flowering time. Healthy and well-rooted plants obtained in a relatively short time ensures their withstanding adverse conditions and the possibility of the perennial alfalfa producing seeds in the year of sowing. The measures to improve plant quality and health include the use of synthetic fertilizers and pesticides. In the context of organic farming, however, it is mandatory to look for other, more efficient and also environmentally safe methods to improve germination, seedling emergence and plant health. One such method can be the use of rhizosphere microorganisms, including the plant growthpromoting rhizobacteria (PGPR) (Chandler et al. 2008; Glick 2012). Numerous authors have reported application of PGPR, via seed coating or as inoculants after seedlings have emerged, to improve seedling growth of many plants
(Khan et al. 1990; Glick 1995; Gholami et al. 2009; Bhattacharyya and Jha 2012). PGPR used include genera such as Bacillus, Pseudomonas, Erwinia, Serratia, Arthrobacter, Micrococcus, Flavobacterium, Azotobacter, Azospirillum, Rhizobium and Agrobacterium (Verma et al. 2010; Glick 2012). Although the mechanisms used by PGPR to directly or indirectly promote plant growth are not fully understood yet, several have been suggested. Based on their mode of action, PGPR are classified as biofertilizers, phytostimulants and biopesticides, although many PGPR often use more than one mode of plant growth enhancement (Bhattacharyya and Jha 2012; Glick 2012). A direct phytostimulation may include the production of phytohormones, e.g., gibberellins, cytokinins and auxins as well as modulation of ethylene level, a gaseous phytohormone, by bacterial ACC deaminase (ACCD) or enhanced provision of nutrients. Indole acetic acid (IAA) produced by bacteria colonizing the plant rhizosphere is considered to act in conjunction with the endogenous plant IAA to stimulate root proliferation and elongation resulting in a more branched root system architecture, which enhances the host's uptake of minerals and nutrients from the soil (Mantelin and Touraine 2004; Mantelin et al. 2006; Spaepen et al. 2007; Shokri and Emtiazi 2010). However, PGPR which do not produce auxin are known to be able to modify the endogenous transport of plant IAA or to regulate auxin homeostasis by, e.g., production of volatile organic compounds (VOC), resulting in the same root architecture effects (Zhang et al. 2007; Contesto et al. 2010; Zamioudis et al. 2013). Some PGPR belonging to fluorescent pseudomonads are well-known producers of the antimicrobial compound 2,4-diacethylphloroglucinol (DAPG) which, at a low concentration, can enhance root branching (Brazelton et al. 2008; Couillerot et al. 2011).

One of the most important factors in seeking an increase of the PGPR efficacy is to find the best bacteria available. Bhattacharyya and Jha (2012) listed the commercially available products used worldwide in plant (mainly cereal) growth promotion, but the list seems to be too short. This is due, i.a., to the fact that neither all the mechanisms the bacteria use for promoting plant growth have been fully elucidated, nor the plant response mechanisms during PGPR treatment are completely known (Vacheron et al. 2013).

Thus, it is essential to explain these mechanisms at various levels, including molecular. Such studies should avoid using Arabidopsis thaliana, a weed serving to date as a molecular model, but should instead use a crop plant, Medicago truncatula Gaertn. known as the barrel medic. In recent years has this plant gained great interest; its attractiveness compared with alfalfa ( $M$. sativa) is related to its more rapid vegetative growth (12-16 weeks from seed to seed) and a high seed production, associated with low 
requirements for light, temperature, and substrate composition. In contrast to the alfalfa, it does not require pollinators such as bees (Cook 1999; Rose 2008). Moreover, $M$. truncatula belongs to the phylogenetic group which also includes alfalfa, peas, beans, chickpeas and clover. It can, thus serve as a model plant because it has a small diploid genome which is already known (alfalfa is tetraploid). Furthermore, genetic mapping of $M$. truncatula and $M$. sativa showed a high level of synteny. This fact will allow future use of genetic and genomic tools, created on the basis of M. truncatula, to improve productivity and cultivation of alfalfa by, i.a., understanding of plant growth promotion mechanisms by PGPR. It is a model plant for molecular and genetic studies of legumes mainly because of its symbiotic association with rhizobia, but also on account of its interaction with other non-symbiotic growthpromoting bacteria (PGPR), arbuscular mycorrhiza (AM) fungi or pests and pathogens (Barker et al. 1990; Hohnjec et al. 2006; Rose 2008).

To date, no reports on the application of rhizobacteria to promote the development of $M$. truncatula have been published, and no data on bacteria species identified from the M. sativa rhizosphere. Therefore, the work reported here was aimed at: (1) isolating bacteria from the rhizosphere of the legume M. sativa L.; (2) evaluating their physiological and genetic characteristics; (3) screening them for their promoting capacities with respect to $M$. truncatula Gaertn., and finally evaluating their application as environmentally friendly adjuncts to agriculture practice-as biostimulants and biofertilizers.

\section{Materials and methods}

\section{Isolation of rhizobacteria}

Strains of bacteria were isolated from the rhizosphere and nodules of $M$. sativa $\mathrm{L}$. from the region of Western Pomerania in Poland. The Medicago roots were washed with $5 \mathrm{ml}$ of sterile distilled water and the soil solution, thus, obtained was used for isolation of non-symbiotic bacteria using the method of Penrose and Glick (2003) with some modifications. The root nodules were separated from the roots and sterilized in $95 \%$ ethanol for $5 \mathrm{~min}$; they were then rinsed with sterile water and homogenized using a micro-pestle. The root nodule homogenate was used for isolation of symbiotic bacteria. The soil solution and the nodule homogenate were placed in $20 \mathrm{ml}$ of Tryptic Soy Broth (TSB) and 2xYT (Liquid Yeast Tryptic) medium, respectively, in 50-ml Falcon tubes. The suspensions were incubated in a shaker incubator $(200 \mathrm{rpm})$ at $28{ }^{\circ} \mathrm{C}$. After $24 \mathrm{~h}$, a $1 \mathrm{ml}$ of the growing culture was transferred to
$20 \mathrm{ml}$ of TSB or 2xYT medium and incubated for another $24 \mathrm{~h}$. Following the two incubations, $1 \mathrm{ml}$ of both suspensions each was transferred to $20 \mathrm{ml}$ of minimal medium and DF salts (Dworkin and Foster 1958), respectively, supplemented with ammonium sulfate or M9 salts supplemented with ammonium chloride as a nitrogen source. After incubation, a $1 \mathrm{ml}$ aliquot was removed from the culture and transferred to $20 \mathrm{ml}$ DF salts or M9 salts with $5 \mathrm{mM} \mathrm{ACC}$ as a source of nitrogen, and was grown for $24 \mathrm{~h}$ under conditions identical as those used in the first incubation. A $100 \mu \mathrm{l}$ portion of the final culture was plated onto solid DF or M9 salts minimal medium containing $5 \mathrm{mM} \mathrm{ACC}$ and $2 \%$ Bacto-Agar, and was incubated for $72 \mathrm{~h}$ at $28{ }^{\circ} \mathrm{C}$. Morphologically different colonies appearing on the medium were isolated and purified by streaking on plates with the same medium, placed in cryovials (Scharlau Cryoinstant) and kept at $-80{ }^{\circ} \mathrm{C}$ for further characterization and identification.

\section{Phenotypic characterization of bacterial isolates}

Physiological and biochemical characteristics of the bacterial isolates were examined according to the methods described in Bergey's Manual of Determinative Bacteriology (Holt et al. 1994). The bacterial isolates were grown on Tryptic Soy Agar (TSA) at $28^{\circ} \mathrm{C}$ for $24 \mathrm{~h}$. Phenotypic characterization of the isolates was conducted based on their colony morphology. Subsequently, the cellular morphology of pure cultures of the isolate (after Gram staining) was analyzed by light microscopy. PGPR motility was determined and some standard biochemical tests (starch hydrolysis, lactose fermentation, resistance to streptomycin and ability to fluorescence) were applied following methods described in Bergey's Manual of Determinative Bacteriology (Holt et al. 1994).

\section{PCR amplification and sequencing}

All the strains isolated were characterized based on $16 \mathrm{~S}$ ribosomal RNA (rRNA) gene sequences and additionally on the $r p o D$ (coding RNA polymerase sigma factor) and gyrB (coding gyrase B) genes of the strains assigned to the genus Pseudomonas (Cladera et al. 2004). The bacteria were cultured in TSB or $2 \mathrm{xYT}$ medium at $28^{\circ} \mathrm{C}$ (the shaker set at $200 \mathrm{rpm}$ ). A $1-\mathrm{ml}$ portion of the cell suspension was centrifuged at $5000 \mathrm{~g}$ for $10 \mathrm{~min}$. The cell pellets were resuspended in $300 \mu \mathrm{l}$ lyse buffer and used to purify the genomic DNA using the DNA Extraction Kit (Eurx, Gdansk, Poland). The following primers were used for the polymerase chain reaction (PCR) amplification of the 16S ribosomal RNA: 16S rRNA-F (5'-AGCGGCG GACGGGTGAGTAATG-3') and 16S rRNA-R (5'-AAG 
GAGGGGATCCAGCCGCA-3') (Young et al. 2004) and UP-1E (5'-CAGGAAACAGCTATGACCAYGSNGGNG GNAARTTYRA- $\left.3^{\prime}\right)$ and APrU (5'-TGTAAAACGACGG CCAGTGCNGGRTCYTTYTCYTGRCA-3') for $g y r B$ gene amplification and 70Fs (5'-ACGACTGACCCGGT ACGCATGTA- $3^{\prime}$ ) and 70Rs ( $5^{\prime}$-ATAGAAATAACCAGA CGTAAGTT-3') for $r p o D$ gene amplification (Yamamoto et al. 2000; Cladera et al. 2004). The all gene amplification was performed in $25 \mu \mathrm{l}$ of the reaction mixture containing $1 \mu \mathrm{M}$ of primers, $0.2 \mu \mathrm{M}$ of each dNTP, $4 \mathrm{mM} \mathrm{MgCl}_{2}, 1 \mathrm{U}$ Taq DNA Hot Start polymerase (Promega) and $1 \mu \mathrm{l}$ of DNA template. PCR was performed in a thermal cycler (Biometra) with an initial denaturation $\left(96{ }^{\circ} \mathrm{C}\right.$ for $2 \mathrm{~min}$ ) followed by 35 cycles of amplification (denaturation at $96{ }^{\circ} \mathrm{C}$ for $15 \mathrm{~s}$, annealing at $58^{\circ} \mathrm{C}$ for $16 \mathrm{~S}$ rRNA and $50{ }^{\circ} \mathrm{C}$ for $r p o D$ and $\operatorname{gyr} B$ for $15 \mathrm{~s}$, extension at $72{ }^{\circ} \mathrm{C}$ for $1 \mathrm{~min} 30 \mathrm{~s}$ for $16 \mathrm{~S}$ rRNA and $45 \mathrm{~s}$ for $r p o D$ and $g y r B$ ) and the single final extension $\left(72{ }^{\circ} \mathrm{C}\right.$ for $\left.5 \mathrm{~min}\right)$. A $2-\mu \mathrm{l}$ aliquot of amplified PCR product was separated by gel electrophoresis in $1 \%$ agarose with ethidium bromide in TBE buffer for $30 \mathrm{~min}$ and viewed under UV light. The 1500, 786 and 849 bp-long products of 16S rRNA, rpoD and gyrB, respectively, were purified using the QIAquick PCR Purification Kit (Qiagen) and sequenced by Genomed (Warszawa, Poland).

Multiple-sequence alignments of $16 \mathrm{~S}$ rRNA, rpoD and gyrB sequences were constructed with CLUSTAL W2 software, and maximum likelihood trees were constructed with the neighbour-joining technique (Saitou and Nei 1987) using MEGA v. 6.0 software subjected to BLAST analysis (Tamura et al. 2013) with those deposited in the GenBank in NCBI database (http://www.blast.ncbi.nlm. nih.gov). Bootstrap tests using 1000 replicates were performed to test the robustness of each phylogeny (Felsenstein 1985).

\section{Growth room pot experiment}

The soil mixture containing sand and perlite $(1: 1, w / w)$ was sterilized in an autoclave under pressure for $30 \mathrm{~min}$ during two consecutive days, and the mixture was placed in $9 \times 9 \mathrm{~cm}$ plastic pots. The seeds of M. truncatula Gaertn. Jemalong J5 ecotype (provided by INRA, Versailles, France) were sterilized and scarified using $95 \% \mathrm{H}_{2} \mathrm{SO}_{4}$ for $10 \mathrm{~min}$, rinsed thoroughly with sterile distilled water, placed on water-saturated Whatman No. 1 disks in Petri dishes, and incubated at $4{ }^{\circ} \mathrm{C}$ for 4 days. Subsequently, the seeds were incubated at $20^{\circ} \mathrm{C}$ for $24 \mathrm{~h}$ and the seedlings were planted in the pots. The seedlings were grown for 1 week under controlled growth room conditions with lightdark and temperature cycles $\left(16 \mathrm{~h}\right.$ light at $24{ }^{\circ} \mathrm{C} ; 8 \mathrm{~h}$ dark at $20{ }^{\circ} \mathrm{C}$ ). The light density was $150 \mu \mathrm{mol} \mathrm{m}{ }^{-2} \mathrm{~s}^{-1}$ (Green Power LED modules, Philips). The one-week-old seedlings were inoculated with $10 \mathrm{ml}$ bacteria inoculum (density of $10^{8} \mathrm{CFU} \mathrm{ml}{ }^{-1}$ ) or $10 \mathrm{mM} \mathrm{MgSO}_{4}$. The inoculum of nonsymbiotic and symbiotic bacteria was prepared by growing bacterial cells in $20 \mathrm{ml}$ of TSB and 2xYT medium, respectively, and incubated in a shaker incubator (200 rpm) at $28{ }^{\circ} \mathrm{C}$. The density of each culture was measured in a Shimadzu UV-Vis 1800 spectrophotometer at $600 \mathrm{~nm}$. The medium was subsequently separated from the culture by centrifugation $\left(8000 \mathrm{~g} / 10 \mathrm{~min} / 4{ }^{\circ} \mathrm{C}\right)$. The cells were suspended in $20 \mathrm{ml}$ of sterile $10 \mathrm{mM} \mathrm{MgSO}_{4}$. Following centrifugation $\left(8000 \mathrm{~g} / 10 \mathrm{~min} / 4{ }^{\circ} \mathrm{C}\right)$, the supernatant was discarded and the washing procedure was repeated twice. The cell suspension was diluted fivefold by the addition of sterile $10 \mathrm{mM} \mathrm{MgSO}_{4}$, and $10 \mathrm{ml}$ portions of the dilution were used for seedling inoculation with a pipette, at a distance of $1 \mathrm{~cm}$ from the stem. The plants were irrigated with distilled water. The soil was fertilized once a week with $\mathrm{N}$-low fertilizer (pH 5.8) containing $\left(\mathrm{mg} \mathrm{l}^{-1}\right)$ : $\mathrm{KNO}_{3}$ (13), $\mathrm{KH}_{2} \mathrm{PO}_{4}$ (17), $\mathrm{CaCl}_{2} \times \mathrm{H}_{2} \mathrm{O}$ (46), $\mathrm{MgSO}_{4} \times 7 \mathrm{H}_{2} \mathrm{O}$ (15), $\mathrm{K}_{2} \mathrm{SO}_{4}$ (27), $\mathrm{EDTA}_{2} \mathrm{Na}_{2} \mathrm{Fe}$ (5) and microtraces $\left(\mu \mathrm{g} \mathrm{l}^{-1}\right)$ of: $\mathrm{H}_{3} \mathrm{BO}_{3}(371), \mathrm{MnSO}_{4} \times \mathrm{H}_{2} \mathrm{O}(209), \mathrm{KCl}$ (337), $\mathrm{ZnSO}_{4} \times 7 \mathrm{H}_{2} \mathrm{O}(33),\left(\mathrm{NH}_{4}\right)_{6} \mathrm{Mo}_{7} \mathrm{O}_{24} \times 4 \mathrm{H}_{2} \mathrm{O}$ (33), $\mathrm{CuSO}_{4} \times 5 \mathrm{H}_{2} \mathrm{O}$ (17), $\mathrm{H}_{2} \mathrm{SO}_{4}$ (17). The shoot, root fresh and dry (dried at $105{ }^{\circ} \mathrm{C}$ for $24 \mathrm{~h}$ ) weights were determined 4 weeks after inoculation.

\section{Plant growth-promoting traits}

All the strains used in M. truncatula growth experiments were analyzed for their ability to produce indolic compounds, their ACCD activity, siderophore, ammonia and organic acid production as well as for their ability to solubilize phosphate and zinc compounds. Additionally, the phlD gene detection in pseudomonads was analyzed. In addition, the IAA content in leaves after 3 and 7 days from inoculation of 5-week-old seedlings with selected strains was determined.

\section{Bacterial indolic compounds production}

The indole compounds quantification was performed with Salkowski's reagent (Khalid et al. 2004). The non-symbiotic and symbiotic bacteria were cultured overnight in $10 \mathrm{ml}$ of TSB and 2xYT medium, respectively, in a shaker incubator $(200 \mathrm{rpm})$ in the dark at $28{ }^{\circ} \mathrm{C}$. Subsequently, $20 \mu \mathrm{l}$ aliquots were transferred to $8 \mathrm{ml}$ of DF or M9 salts minimal medium supplemented with L-tryptophan $\left(500 \mu \mathrm{g} \mathrm{ml}^{-1}\right)$. The density of each culture was measured spectrophotometrically at $600 \mathrm{~nm}$ (ca. $5 \times 10^{8}$ $\mathrm{CFU} \mathrm{m}{ }^{-1}$ ). Subsequently, the bacterial cells were removed from the culture medium by centrifugation $(8000 \mathrm{~g} / 10 \mathrm{~min})$. A $1-\mathrm{ml}$ aliquot of the supernatant was mixed vigorously with $4 \mathrm{ml}$ of Salkowski's reagent 
(150 ml of concentrated $\mathrm{H}_{2} \mathrm{SO}_{4}, 250 \mathrm{ml}$ of distilled water, $7.5 \mathrm{ml}$ of $0.5 \mathrm{M} \mathrm{FeCl}_{3} \times 6 \mathrm{H}_{2} \mathrm{O}$ ) and incubated at $20^{\circ} \mathrm{C}$ for $20 \mathrm{~min}$. Indole production was measured spectrophotometrically using absorbance at $535 \mathrm{~nm}$. The concentration of indolic compounds in each culture medium was determined by comparison with a standard curve plotted for pure IAA (Sigma-Aldrich) and reported as $\mu \mathrm{g} \mathrm{IAA} \mathrm{ml}^{-1}$ of bacterial culture (density ca. $5 \times 10^{8} \mathrm{CFU} \mathrm{ml}^{-1}$ ).

\section{ACC deaminase activity}

The ACCD activity was measured by a modified ACCD activity assay following Penrose and Glick (2003) and Honma and Shimomura (1978). The bacterial cells were incubated overnight in $20 \mathrm{ml}$ of TSB or 2xYT medium in a shaker incubator $(200 \mathrm{rpm})$ at $28{ }^{\circ} \mathrm{C}$. After incubation, the bacterial culture was centrifuged $\left(8000 \mathrm{~g} / 10 \mathrm{~min} / 4{ }^{\circ} \mathrm{C}\right)$. The supernatant was removed and the cells were washed with $10 \mathrm{ml}$ DF or M9 salts minimal medium, and centrifuged again. The cells were suspended in $7.5 \mathrm{ml} \mathrm{DF}$ or M9 salts minimal medium with $5 \mathrm{mM}$ ACC. The bacterial cells were incubated at $28{ }^{\circ} \mathrm{C}$ for $24 \mathrm{~h}$. The culture was centrifuged $\left(8000 \mathrm{~g} / 10 \mathrm{~min} / 4{ }^{\circ} \mathrm{C}\right)$, the supernatant was removed, and the cells were washed with $0.1 \mathrm{M}$ Tris- $\mathrm{HCl}$ ( $\mathrm{pH}$ 7.6). The washing procedure was repeated twice. A $1-\mathrm{ml}$ bacterial suspension was centrifuged at $16,000 \mathrm{~g}$ for $5 \mathrm{~min}$ and the supernatant was removed. The pellet was suspended in $600 \mu \mathrm{l} 0.1 \mathrm{M}$ Tris- $\mathrm{HCl}(\mathrm{pH} \mathrm{8.0)}$ to which $300 \mu$ toluene were added, and the cell suspension was vortexed for $30 \mathrm{~s}$. A $100-\mu \mathrm{l}$ aliquot of protein extract was kept from each sample to determine protein concentration of each sample using the Bradford method (Bradford 1976). Toluenized cells $(200 \mu \mathrm{l})$ were placed in microcentrifuge tubes with $20 \mu \mathrm{l}$ of $0.5 \mathrm{M} \mathrm{ACC}$ and incubated at $30{ }^{\circ} \mathrm{C}$ for $15 \mathrm{~min}$. Following the addition of $1 \mathrm{ml}$ of $0.56 \mathrm{M} \mathrm{HCl}$ and mixing, the cell suspension was centrifuged $(16,000 \mathrm{~g} / 5 \mathrm{~min} / \mathrm{RT})$. Subsequently, $800 \mu \mathrm{l}$ of $0.56 \mathrm{M} \mathrm{HCl}$ was added to $1 \mathrm{ml}$ of the supernatant and the mixture was vortexed. The dinitrophenylhydrazine reagent $(0.2 \%$ 2,4-DNP in $2 \mathrm{M} \mathrm{HCl})$ in the amount of $300 \mu \mathrm{l}$ was added to the glass tube and incubated at $30{ }^{\circ} \mathrm{C}$ for $30 \mathrm{~min}$. Before the measurement, $2 \mathrm{ml}$ of $2 \mathrm{~N} \mathrm{NaOH}$ was added and the absorbance was measured at $540 \mathrm{~nm}$. The ACCD activity was determined by measuring the production of $\alpha$ ketobutyrate and comparing the result with a standard curve using an $\alpha$-ketobutyrate (Honma and Shimomura 1978). The enzyme activity was expressed as micromoles of $\alpha-\mathrm{KB} \mathrm{mg} \mathrm{protein}{ }^{-1} \mathrm{~h}^{-1}$.

\section{PCR analysis with specific phlD primers}

Bacterial DNA was used for PCR amplification with specific phlD gene primers (Phl2a and Phl2b) designed by
Raaijmakers et al. (1997). PhlD gene amplification was performed in $25 \mu \mathrm{l}$ reaction mixture containing $1 \mu \mathrm{M}$ of each primer, $0.2 \mu \mathrm{M}$ of DNA template each dNTP, $4 \mathrm{mM}$ $\mathrm{MgCl}_{2}, 1 \mathrm{U}$ Tag Hot Start polymerase (Promega) and $1 \mu \mathrm{l}$ of DNA template. This reaction mixture was incubated in a thermal cycler (Biometra) with initial denaturation $\left(96{ }^{\circ} \mathrm{C}\right.$ for $2 \mathrm{~min}$ ) and then cycled 35 times through the following temperature profile: denaturation at $96{ }^{\circ} \mathrm{C}$ for $15 \mathrm{~s}$, annealing at $60{ }^{\circ} \mathrm{C}$ for $15 \mathrm{~s}$, extension at $72{ }^{\circ} \mathrm{C}$ for $1 \mathrm{~min}$, and the single final extension at $72{ }^{\circ} \mathrm{C}$ for $5 \mathrm{~min}$. A $2-\mu \mathrm{l}$ aliquot of the amplified PCR product was separated by gel electrophoresis in $1 \%$ agarose with ethidium bromide in TBE buffer for $30 \mathrm{~min}$ and was visualized with a UV transilluminator. The 720-bp PCR product was sequenced by Genomed. The phylogenetic tree was inferred by the neighbour-joining method using MEGA v 6.0.

\section{Phosphate and zinc compounds solubilization}

The solubilization was detected by the formation of transparent halos (mm) surrounding bacterial colonies on the Pikovskaya medium containing insoluble $\mathrm{CaHO}_{13} \mathrm{P}_{3}$ or $\mathrm{ZnO}$ after 10 days at $28^{\circ} \mathrm{C}$ (Pikovskaya 1948).

\section{Medium acidification}

To detect the ability of the bacterial strains to acidify medium, the isolates were spotted on the TSA medium $(\mathrm{pH}$ 7.5) with bromothymol blue, which allowed to detect acidification (DuPree and Wilcox 1977). The medium surrounding the organic acid-producing strains changed colour from blue to green as $\mathrm{pH}$ dropped below 7 .

\section{Siderophore production}

The siderophore production was detected by the production of orange halos surrounding the bacterial colonies on a standard Chrome Azurol-S (CAS) agar plates after $72 \mathrm{~h}$ at $28^{\circ} \mathrm{C}$ (Schwyn and Neilands 1987; Alexander and Zuberer 1991).

\section{Ammonia production}

The ammonia production by the bacterial strains was determined after their incubation in peptone water for $72 \mathrm{~h}$ at $28{ }^{\circ} \mathrm{C}$ (Cappuccino and Sherman 1992). Nessler's reagent $(0.5 \mathrm{ml})$ was added to each tube. The development of brown to yellow colour was a positive test for the ammonia production.

\section{Protein content determination}

The protein content of the enzyme extract was determined by the dye binding method using the Bradford reagent 
(Sigma-Aldrich) and bovine serum albumin (SigmaAldrich) as standard (Bradford 1976).

\section{IAA determination in seedling leaves by UPLC-MS/ MS}

Extraction and purification of indole-3-acetic acid (IAA) was conducted as described by Novák et al. (2012) with minor modifications. Frozen leaves $(20 \mathrm{mg} \mathrm{FW})$ of 5-week-old seedlings previously inoculated with bacterial suspension of the strains selected during the study (density of $10^{8} \mathrm{CFU} \mathrm{ml}{ }^{-1}$ ) or treated with $10 \mathrm{mM} \mathrm{MgSO}_{4}$ (control) were homogenized using a MixerMill (Retsch $\mathrm{GmbH}$, Haan, Germany) and extracted in $1 \mathrm{ml} 50 \mathrm{mM}$ sodium phosphate buffer ( $\mathrm{pH}$ 7.0) containing $1 \%$ sodium diethyldithiocarbamate and stable isotope-labeled internal standard (5 pmol of ${ }^{13} \mathrm{C}$-IAA per sample). The $\mathrm{pH}$ was adjusted to 2.7 with $1 \mathrm{M}$ hydrochloric acid, and the samples were purified by solid phase extraction. The extracts were purified on Oasis HLB columns $(30 \mathrm{mg}$, Waters Corp., Milford, MA, USA), conditioned with $1 \mathrm{ml}$ methanol, $1 \mathrm{ml}$ water and $0.5 \mathrm{ml}$ sodium phosphate buffer $(\mathrm{pH}$ 2.7). After sample application, the column was washed with $2 \mathrm{ml} 5 \%$ methanol and then eluted with $2 \mathrm{ml} 80 \%$ methanol. Eluates were evaporated to dryness and dissolved in $30 \mu \mathrm{l}$ of mobile phase prior to mass analysis using an Acquity UPLC ${ }^{\circledR}$ System and triple quadrupole mass spectrometer Xevo ${ }^{\mathrm{TM}}$ TQ MS (Water) (Floková et al. 2014).

\section{Statistical analysis}

Each experiments was run in five replicates and repeated twice. Analysis of variance (ANOVA), Duncan's multiple range test and Pearson's correlation coefficients were calculated using Statistica for Windows v. 9.0 (StatSoft Inc., Tulsa, OK, USA).

\section{Results}

\section{Isolation and identification of bacterial isolates}

Sixteen bacterial isolates were obtained from the rhizospheric soil and root nodule samples from alfalfa. The first step in characterizing and identifying a bacterial culture involved examination of colony morphology and cell shape. After 24-h incubation of isolates on the TSA medium, the size, shape, edge, texture, height, colour and optical properties of bacterial colonies were determined. Most isolates ( $85 \%$ ) formed small (1-2 mm) and mediumsized $(3 \mathrm{~mm}$ ) colonies. Only two isolates: $\mathrm{KK} 8 \mathrm{~b}$ and $\mathrm{KK}$ 11, formed large colonies, about $4 \mathrm{~mm}$ in diameter.
Colonies formed by most isolates $(75 \%)$ were circular, the remaining $25 \%$ were irregular in shape. All the colonies had smooth edges, their texture being smooth as well. As many as $81 \%$ of the colonies were convex, one (KK 3) was umbonate, one (KK 11) was crater-like, and one (KK 13) was flat. Twelve of the 16 isolates formed creamy colonies, 2 being whitish and 2 yellowish. All the 16 isolates were found to be rod-shaped (data not shown).

The second step in bacteria identification involved determination of physiological and biochemical characteristics of the isolates. Almost all the isolates, except KK $8 \mathrm{a}$, were able to move (Table 1). Seven isolates (KK 1a, KK 1b, KK 2, KK 3, KK 4, KK 9a, KK 11) reacted positively to Gram staining. Most of the isolates tested were able to hydrolyse starch, while only three isolates (KK 6, KK 9a, KK 10) were able to hydrolyse lactose. As few as 4 isolates tested positively in the resistance to streptomycin test. Three isolates (KK 5, KK 7, KK 9b) were able to fluoresce.

Based on the morphological, physiological and biochemical characteristics, only the isolates KK 1a, KK 1b, KK 2, KK 3, KK 4, KK 9a could be assigned to the families Bacillaceae and Listeriaceae, whereas 9 isolates (KK 5, KK 6, KK 7, KK 8a, KK 8b, KK 9b, KK 10, KK 12, KK 13) were placed in the families Pseudomonadaceae, Enterobacteriaceae, Moraxellaceae, Xantomonadaceae, Burkholderiaceae and Rhizobiaceae. 16S rRNA gene sequencing was used to fine-tune the identification of these bacteria. An about $1.5 \mathrm{~kb}$ fragment of 16S rRNA of all the isolates was amplified by PCR products. The PCR products were purified, cloned and sequenced. Nucleotide sequences of the isolates were compared with sequences available in NCBI GenBank. The percentage of $16 \mathrm{~S}$ rRNA gene sequence similarities (97.7-99.8\%) of all the isolates to the closest type strains is shown in Table 2. The data allowed also to create a dendrogram with 5 separate taxonomic groups (Fig. 1). Seven of the 16 isolates isolated from the M. sativa rhizosphere and nodules were assigned to the family Bacillaceae, one to Rhizobiaceae, two to Xantomonadaceae, three to Enterobacteriaceae and three to Pseudomonadaceae. The family Bacillaceae was represented by 3 genera: Bacillus (strains KK 1b, KK 11), Lysinibacillus strains (KK 2, KK 3) and Paenibacillus strains (KK 1a, KK 4, KK 9a) (Table 2; Fig. 1). All strains identified as representing the family Bacillaceae are Grampositive, the remaining 9 strains being Gram-negative. Only one isolate, KK 13 , obtained from the M. sativa nodules belongs to the family Rhizobiaceae and the genus Sinorhizobium (Table 2; Fig. 1). The next two Gram-negative isolates, KK $8 \mathrm{~b}$ and $\mathrm{KK} 9 \mathrm{~b}$, obtained from the $M$. sativa rhizosphere belong to the family Xantomonadaceae and the genus Stenotrophomonas (Table 2; Fig. 1). The further 3 Gram-negative bacterial isolates, KK 8a, KK 10 
Table 1 Physiological and biochemical characteristics of isolates from Medicago sativa rhizosphere and nodules

\begin{tabular}{|c|c|c|c|c|c|c|}
\hline Strain code & Motility ability & Gram staining & Starch hydrolysis & Fermentation of lactose & Streptomycin resistance & Fluorescence \\
\hline KK 1a & + & + & + & - & + & - \\
\hline $\mathrm{KK} 1 \mathrm{~b}$ & + & + & + & - & + & - \\
\hline KK 2 & + & + & + & - & + & - \\
\hline KK 3 & + & + & + & - & - & - \\
\hline KK 4 & + & + & + & - & + & - \\
\hline KK 5 & + & - & +++ & - & - & + \\
\hline KK 6 & + & - & ++ & + & - & - \\
\hline KK 7 & + & - & +++ & - & - & + \\
\hline KK 8a & - & - & ++ & - & - & - \\
\hline $\mathrm{KK} 8 \mathrm{~b}$ & + & - & - & - & - & - \\
\hline KK 9a & + & + & ++ & + & - & - \\
\hline KK 9b & + & - & - & - & - & + \\
\hline KK 10 & + & - & - & + & - & - \\
\hline KK 11 & + & + & + & - & - & - \\
\hline KK 12 & + & - & - & - & - & - \\
\hline $\mathrm{KK} 13^{\mathrm{a}}$ & + & - & - & - & - & - \\
\hline
\end{tabular}

Reaction index: - , negative; + , low; ++ , medium; +++ , high

${ }^{\text {a }}$ Isolated from nodules

Table 2 16S rRNA gene sequencing-based identification of bacteria isolated from Medicago sativa rhizosphere and nodules

\begin{tabular}{llllll}
\hline Strain code & Families & Genus & Closest relative (GenBank no.) & Similarity & GenBank accession no. \\
\hline KK 1b & Bacillaceae & Bacillus & B. niacini (AB021194) & 99.7 & KP858911 \\
KK 11 & & B. megaterium (GU252112) & 98.8 & KP858923 \\
KK 2 & & L. fusiformis (AJ310083) & 99.8 & KP858912 \\
KK 3 & & Paenibacillus & P. . odosiformis (AJ310083) (AJ223990) & 99.7 & KP858913 \\
KK 1a & & P. borealis (AJ011322) & 97.8 & KP858910 \\
KK 4 & & P. amylolyticus (AB073190) & 97.7 & KP858914 \\
KK 9a & & S. meliloti (AL591688) & 98.8 & KP858920 \\
KK 13 & Rhizobiaceae & Sinorhizobium & S. maltophilia (AB294553) & 99.2 & KP858909 \\
KK 8b & Xantomonadaceae & Stenotrophomonas & KP858919 & KP858921 \\
KK 9b & & & C. murliniae (AF025369) & 99.4 & KP858922 \\
KK 10 & Enterobacteriaceae & Citrobacter & L. adecarboxylata (JN175338) & 98.8 & KP858916 \\
KK 6 & & Leclercia & R. planticola (AB680712) & 98.9 & KP858918 \\
KK 8a & & Raoultella & P. brassicacearum (CP002585) & 99.8 & KP858915 \\
KK 5 & Pseudomonadaceae & Pseudomonas & P. corrugata (HM190230) & 99.5 & KP858917 \\
KK 7 & & & P. corrugata (HM190230) & 99.8 & KP858924 \\
KK 12 & & & &
\end{tabular}

and KK 6 represent 3 genus of the family Enterobacteriaceae: Citrobacter, Leclercia and Raoultella (Table 2; Fig. 1). Finally, the family Pseudomonadaceae is represented by 3 isolates (KK 5, KK 7 and KK 12) identified as representing the genus Pseudomonas (Table 2; Fig. 1). The use of house-keeping genes $r p o D$ (Fig. 2a) and gyrB (Fig. 2b) in the taxonomic study of the 3 Pseudomonas strains confirmed that the strains $\mathrm{KK} 5$, KK 7 and KK 12 belong to the species listed in Table 2 .

\section{Effects of the bacteria identified on M. truncatula seedling growth}

Inoculation of 1-week-old $M$. truncatula seedlings (Fig. 3a), grown in soil mixture under controlled conditions, with a suspension of all the strains identified had a positive effect on the seedling development 4 weeks after inoculation (Fig. 3c-r) compared with that of the control (Fig. 3b). Six of the 16 strains showed a particularly high 
KK7

Pseudomonas sp. UW4

86 Pseudomonas kilonensis strain 520-20

Pseudomonas corrugata CFBP 5454

78 KK12

Pseudomonas corrugata NCPPB 24451

63 Pseudomonas fluorescens NCIMB 11764

Pseudomonas fluorescens A506

Pseudomonas fluorescens F113

7690 Pseudomonas fluorescens SBW25

68 Pseudomonas fluorescens strain LBUM223

seudomonadaceae

100

Pseudomonas fluorescens strain PCL1751

96

77

KK5

@2 Pseudomonas brassicacearum subsp. brassicacearum NFM421

Pseudomonas fluorescens PfO-1

100

Bacillaceae

Rhizobiaceae

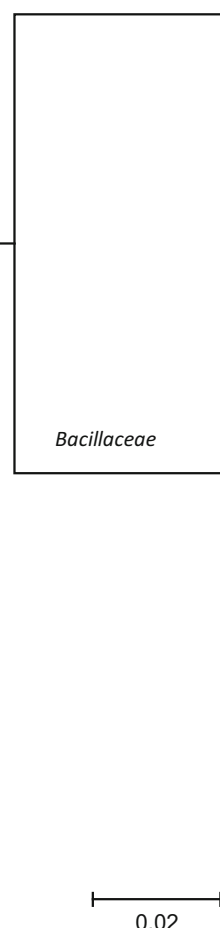

0.02
$88 \mathrm{KK} 8 \mathrm{~b}$

$\mathrm{KK} 9 \mathrm{~b}$

100

Stenotrophomonas maltophilia R551-3

St

Sinorhizobium meliloti LMG 6133

100 Sinorhizobium meliloti NBRC 14782

Sinorhizobium meliloti 1021

KK13

Paenibacillus borealis KK19

77 Paenibacillus typhae strain xj7

61 Paenibacillus odorifer TOD45

100 Paenibacillus borealis KK19 DSM 13188

100

${ }_{84}{ }_{\text {KK4 }}$

KK9a

100

Paenibacillus amylolyticus NBRC 15957

Paenibacillus tundrae $\mathrm{A} 10 \mathrm{~b}$

Bacillus megaterium QM B1551

KK11

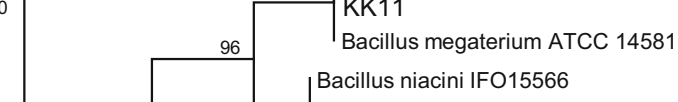

98

100

KK1b

72 Lysinibacillus sphaericus DSM 28

Lysinibacillus sphaericus NBRC 15095

$100 \quad$ KK3

${ }_{74} \mathrm{KK} 2$

Lysinibacillus fusiformis DSM 2898

Lysinibacillus fusiformis NBRC 15717 
seedling growth promotion ability: Paenibacillus borealis KK 4 (Fig. 3h), Raoultella planticola KK 8a (Fig. 3o), Sinorhizobium meliloti KK 13 (Fig. 3j), Pseudomonas

4Fig. 1 16S rRNA gene sequence-based phylogenetic tree (not rooted) showing position of 16 isolates from Medicago sativa rhizosphere and nodules in relation to taxonomically similar bacteria. The analysis was conducted using the neighbor-joining test. The scale bar indicates 0.02 changes/site. Bootstraps of 1000 replicates were used and are shown at the branch nodes of the phylogenetic tree brassicacearum KK 5 (Fig. 3p), Citrobacter murliniae KK 10 (Fig. 3m) and Bacillus niacini KK 1b (Fig. 3c). These bacteria induced a high increase in fresh weight of the roots, 2.2-2.5 times higher than that of the control. Their beneficial effect was also observed in growth of shoots; their fresh weight was almost 3-4.7 times higher that of the control. The bacterial promotional effect on the seedling growth involves not only their impact on the root weight, but also the root architecture. After the seedlings had been inoculated with a suspension of $P$. borealis KK 4 (Fig. 3h)

(a)

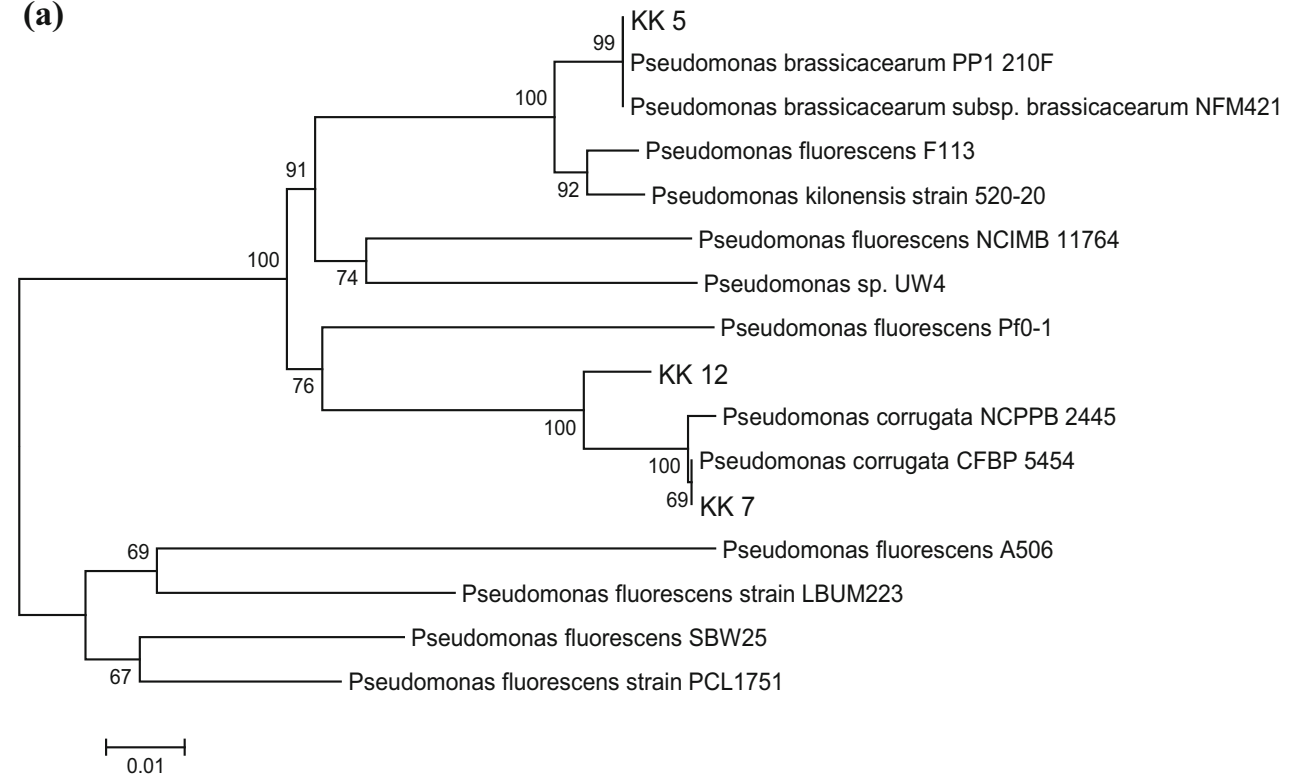

(b)

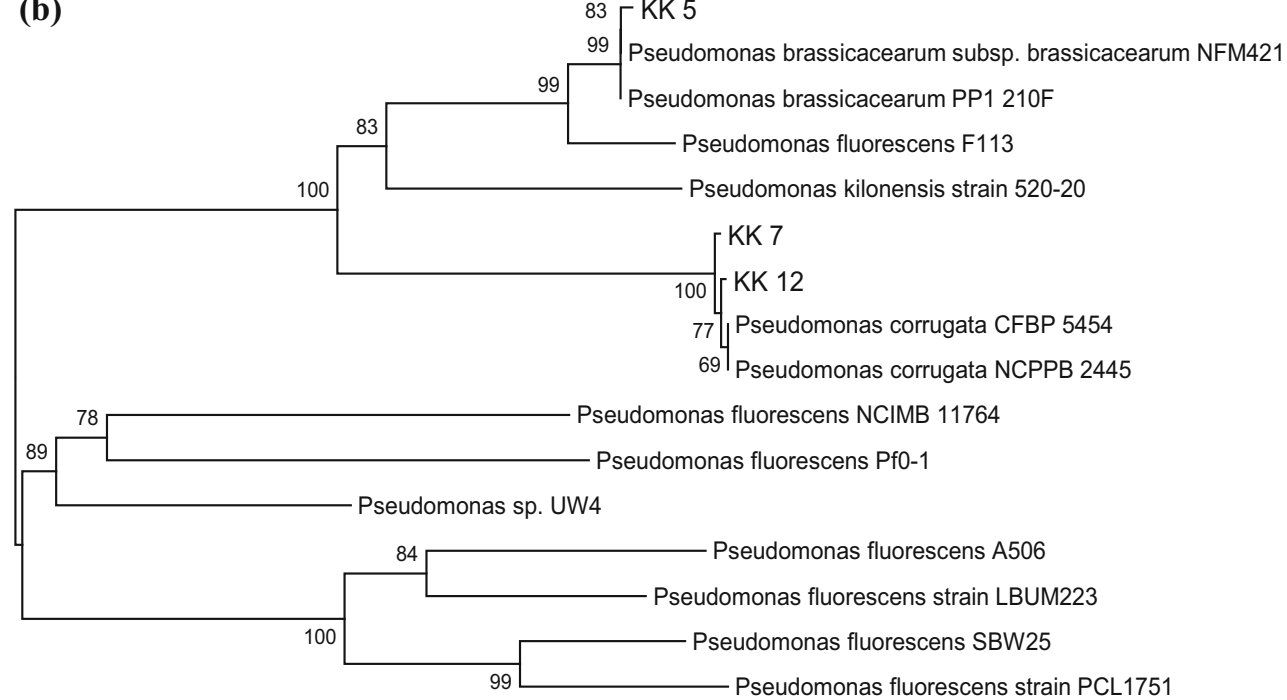

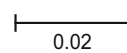

Fig. 2 Phylogenetic tree (not rooted) based on rpoD (a) and gyr B (b) gene sequence showing position of 3 Pseudomonas isolates from Medicago sativa rhizosphere in relation to taxonomically similar bacteria. The analysis was conducted using the neighbor-joining test.
The scale bar indicates 0.01 (a) and 0.02 (b) changes/site. Bootstraps of 1000 replicates were used and are shown at the branch nodes of the phylogenetic tree 
Fig. 3 Effects of bacteria isolated from Medicago sativa rhizosphere and nodules on Medicago truncatula shoot and root growth 4 weeks after inoculation (c-r). Two-way ANOVA with Duncan's multiple range test was used to detect significant differences. Means denoted with different letters $(\mathbf{a}-\mathbf{g})$ are significantly different $(P \leq 0.05)$
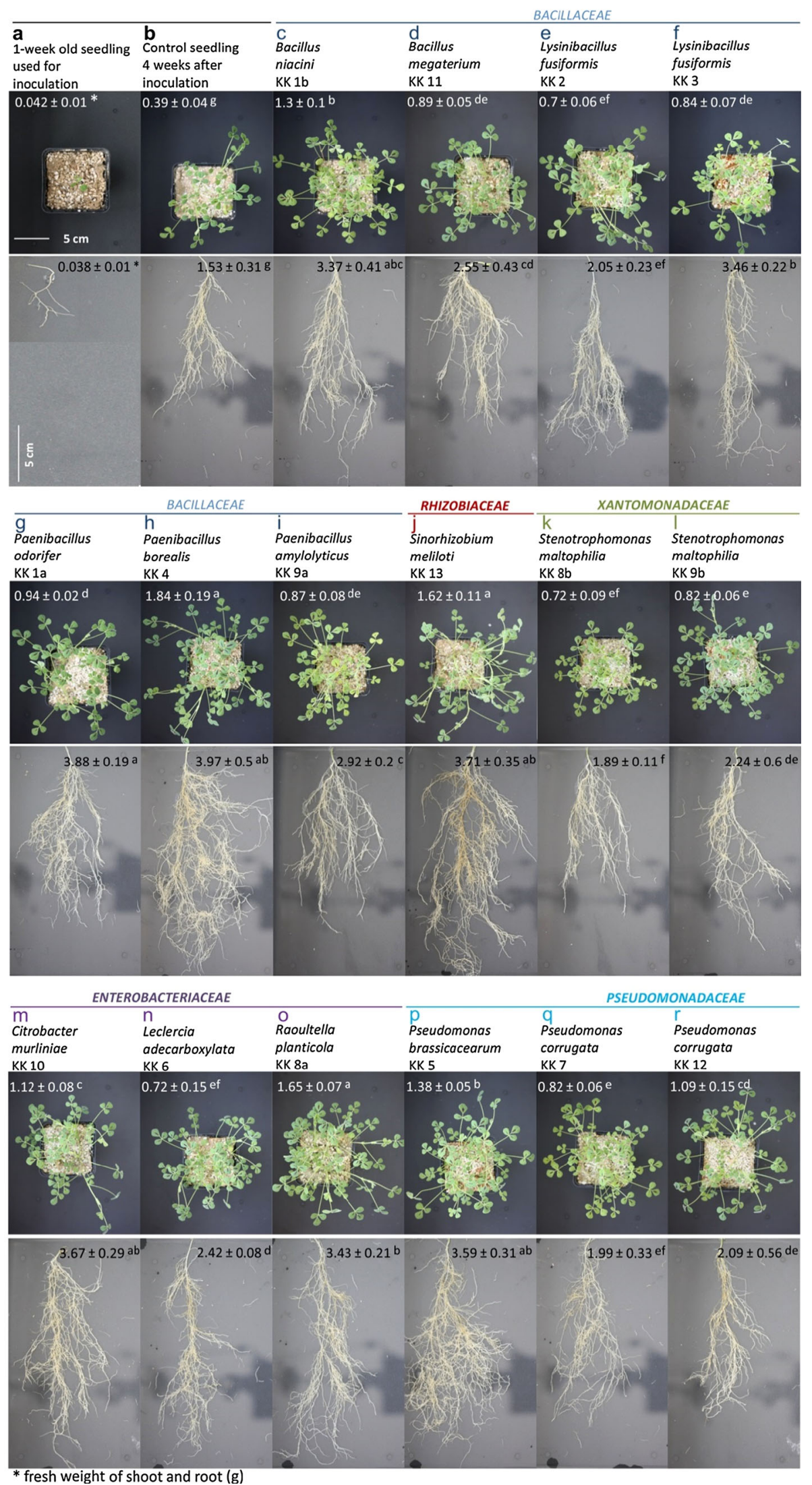
and P. odorifer KK 1a (Fig. 3g), they produced the same root fresh weight (ca. $4.0 \mathrm{~g}$ ), but the architecture of the roots was different. The roots of the seedlings inoculated with $P$. borealis KK 4 were more branched than the roots of seedlings inoculated with $P$. odorifer $\mathrm{KK} 1 \mathrm{a}$ and the fresh shoot weight of the seedlings was twice of that of the latter. Similarly to $P$. borealis $\mathrm{KK} 4$, other bacteria $(R$. planticola KK 8a, S. meliloti KK 13, P. brassicacearum KK 5, C. murliniae KK 10 and B. niacini KK 1b) which had a positive impact on the shoot weight increase, distinctly stimulated root branching (Fig. 3o, j, p, m, c). The weakest promotion of root and shoot growth was observed after seedling inoculation with suspensions of KK $8 \mathrm{~b}$ strain closest relative to Stenotrophomonas maltophilia, Pseudomonas corrugata KK 7 and Lysinibacillus fusiformis KK 2 (Fig. 3k, q, e). Four weeks after inoculation, the seedlings treated with these bacteria showed the least branched roots and the lowest root weight (between 1.89 and $2.05 \mathrm{~g}$ ), although the weight was still higher than that in the noninoculated controls. The beneficial effect of inoculation with all the strains was confirmed by data on dry weights of shoots (Fig. 4a), roots (Fig. 4b) and whole seedlings (Fig. 4c) which were all higher than those of the untreated seedlings. The shoot dry weight was the highest in plants inoculated with $R$. planticola KK 8a, $P$. borealis KK 4, $P$. brassicacearum KK 5, S. meliloti KK 13 and B. niacini KK $1 \mathrm{~b}$, which were $6.5,6.3,5.0,4.8$ and 4.6 times higher, respectively, than in control plants (Fig. 4a). Inoculation with the remaining 11 strains also substantially (from about 2.0-3.0 times) increased the shoot dry weight, compared to the control. The strain $C$. murliniae KK 10 was the most effective promoter of root biomass (Fig. $4 \mathrm{~b}$ ). The isolate increased the root dry weight 7 times ( $299 \mathrm{mg}$ ), compared with the control (43 mg). The strains $S$. meliloti KK 13, Paenibacillus odorifer KK 1a, P. borealis KK 4, L. fusiformis $\mathrm{KK} 3$ and $R$. planticola $\mathrm{KK} 8$ a produced also a marked positive effect on the root dry weight, compared with the non-inoculated control seedlings; the root weight of the treated seedlings was more than 5 times higher (223-250 mg) than that of controls. Four weeks after inoculation with all the strains, whole seedling biomass was several times higher than that of the non-inoculated plants (Fig. 4c). The most effective strains were again $P$. borealis KK 4, R. planticola KK 8a, S. meliloti KK 13, P. brassicacearum KK 5, C. murliniae KK 10 and B. niacini KK $1 \mathrm{~b}$; the seedling dry weights $6.0,5.8,5.2,4.8,4.6$ and 4.5 times higher than those of the control, respectively.

\section{Bacterial indolic compounds production, ACC deaminase activity and the presence of $p h l \mathrm{D}$ gene}

We also evaluated the ability of the strains showing a phytostimulation effect on $M$. truncatula seedlings to produce indolic compounds and examined them with respect to the ACCD responsible for modulation of the rhizosphere ethylene content. All the strains were capable of indolic compounds biosynthesis in the presence of $\mathrm{L}^{-}$ tryptophan, the amount produced being found to range from about $4-47 \mu \mathrm{g}$ per $1 \mathrm{ml}$ of suspension with a density of $5 \times 10^{8}$ cells ml ${ }^{-1}$ (Table 3 ). The highest amount of these compounds produced resulted from effects of $S$. meliloti $\mathrm{KK} 13\left(47.2 \mu \mathrm{g} \mathrm{ml}^{-1}\right), P$. corrugata $\mathrm{KK} 12$ $\left(46.8 \mu \mathrm{g} \mathrm{ml}^{-1}\right), P$. borealis $\mathrm{KK} 4\left(41.1 \mu \mathrm{g} \mathrm{ml}^{-1}\right)$ and $R$. planticola $\mathrm{KK} 8 \mathrm{a}\left(41.1 \mu \mathrm{g} \mathrm{ml}^{-1}\right)$; the lowest amounts being induced by $P$. brassicacearum KK $5\left(4.0 \mu \mathrm{g} \mathrm{ml}^{-1}\right)$. The ability to produce indolic compounds depends not only on a species, but also on a strain; $P$. brassicacearum (KK 5) produced the lowest amount of these compounds among all the strains tested. However, even different strains within a species differed in their ability to produce the indolic compounds: while $P$. corrugata KK 7 produced $24.8 \mu \mathrm{g} \mathrm{ml}^{-1}$, P. corrugata KK 12 produced almost twice that, $46.8 \mu \mathrm{g} \mathrm{ml}^{-1}$ (Table 3). The same observation was made when the production of these compounds by three species of Paenibacillus was analyzed; P. amylolyticus KK 9a, $P$. odorifer KK 1a and P. borealis KK 4 produced 29.7, 34.5 and $41.1 \mu \mathrm{g} \mathrm{ml}^{-1}$, respectively. On the other hand, very similar amounts of indolic compounds were synthesized by both Bacillus species: B. niacini KK $1 \mathrm{~b}$ and $B$. megaterium $\mathrm{KK} 11$ produced 37.1 and $36.8 \mu \mathrm{g} \mathrm{ml}^{-1}$, respectively.

Of the 16 strains, 14 were able to grow on the ACCcontaining medium as the sole nitrogen source (Table 3). These strains, representing 13 species, expressed the ACCD activity at levels ranging from 0.4 to about $1469.2 \mu \mathrm{mol} \alpha-\mathrm{KB}$ mg protein ${ }^{-1} \mathrm{~h}^{-1}$. The highest ACCD activity $\left(1469.2 \mu \mathrm{mol} \alpha-\mathrm{KB} \mathrm{mg} \operatorname{protein}^{-1} \mathrm{~h}^{-1}\right)$ was exhibited by $P$. brassicacearum KK 5 , followed by $B$. megaterium KK $11\left(345.3 \mu \mathrm{mol} \alpha-\mathrm{KB}\right.$ mg protein $\left.{ }^{-1} \mathrm{~h}^{-1}\right)$ and $P$. corrugata KK $7\left(108.2 \mu \mathrm{mol} \alpha-\mathrm{KB} \mathrm{mg} \mathrm{protein}^{-1}\right.$ $\mathrm{h}^{-1}$ ). The ACCD activity in 8 strains was very low. Those strains include all the three strains representing the Enterobacteriaceae, 4 from the Bacillaceae and one from the Xantomonadaceae. Two strains: P. amylolyticus KK 9a and S. meliloti KK 13 showed no ACCD activity.

The analyses described above were conducted to assess the potential of the strains to be used as phytostimulants. The seedlings inoculated with strains which did not produce ACCD, but differed in their ability to produce phenolic compounds showed a different reaction in terms of the root and shoot growth. S. meliloti KK 13 producing 2 times higher amounts of indolic compounds $\left(47.2 \mu \mathrm{g} \mathrm{ml}^{-1}\right)$, compared to $S$. maltophilia $\mathrm{KK} 9 \mathrm{~b}$ (23.2 $\mu \mathrm{g} \mathrm{ml}^{-1}$; Table 3) induced also a nearly twofold increase in the fresh weight of both roots and shoots (Fig. 3j, l) as well as in their dry weights (Fig. 4a, b). The 
Fig. 4 Effects of bacteria isolated from Medicago sativa rhizosphere and nodules on dry mass of Medicago truncatula shoots (a), roots (b) and seedlings (c) 4 weeks after inoculation. Vertical bars indicate \pm SD. Two-way ANOVA with Duncan's multiple range test was used to detect significant differences. Means denoted with different letters $(\mathbf{a}-\mathbf{g})$ are significantly different $(P \leq 0.05)$

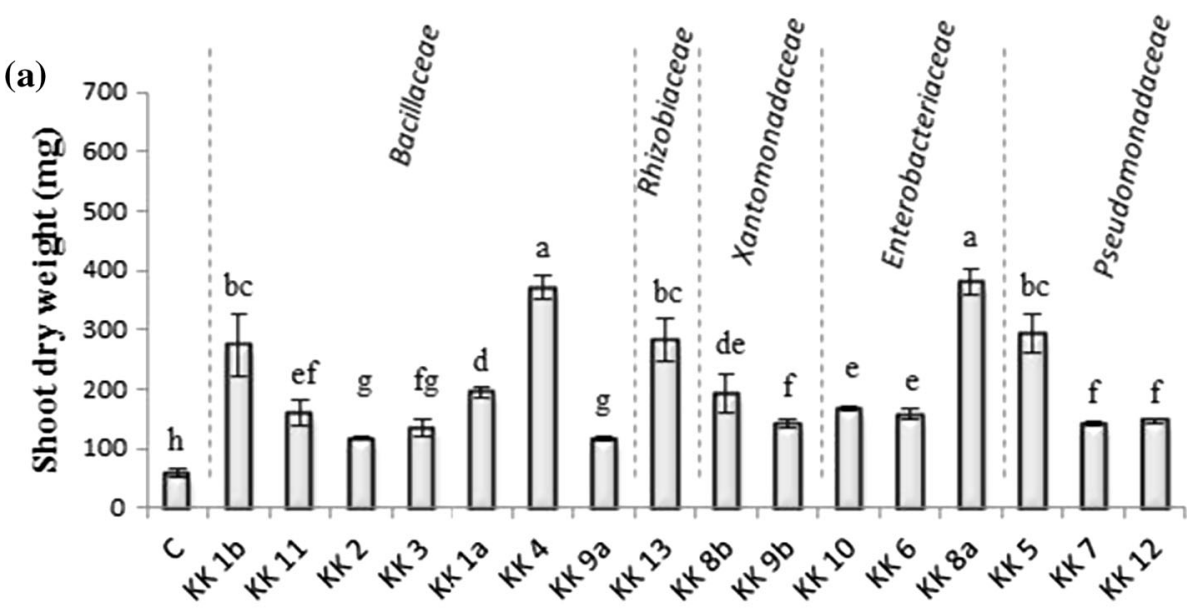

(b)

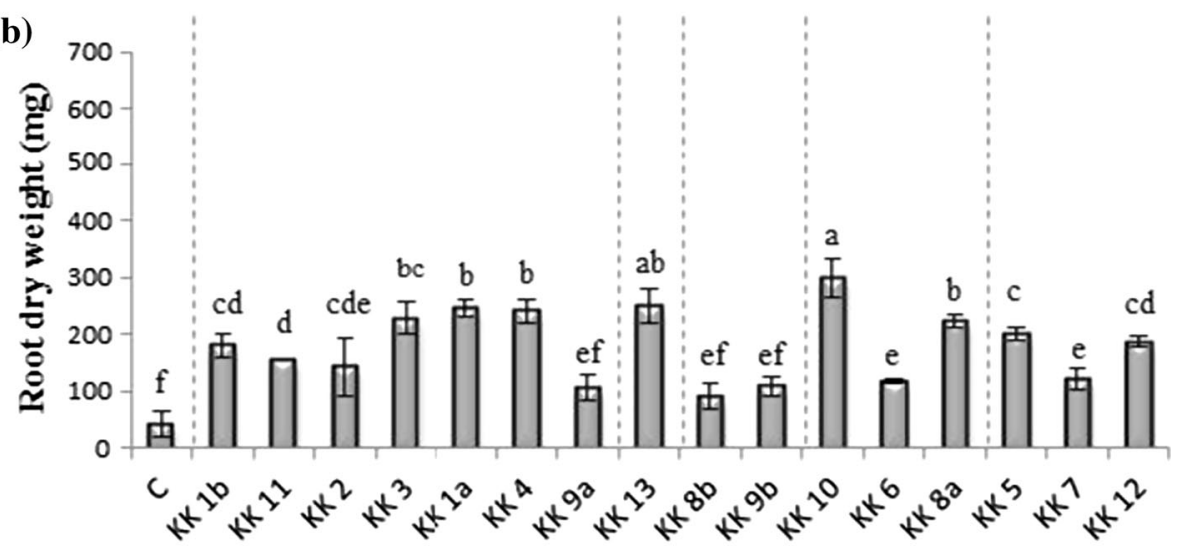

(c)

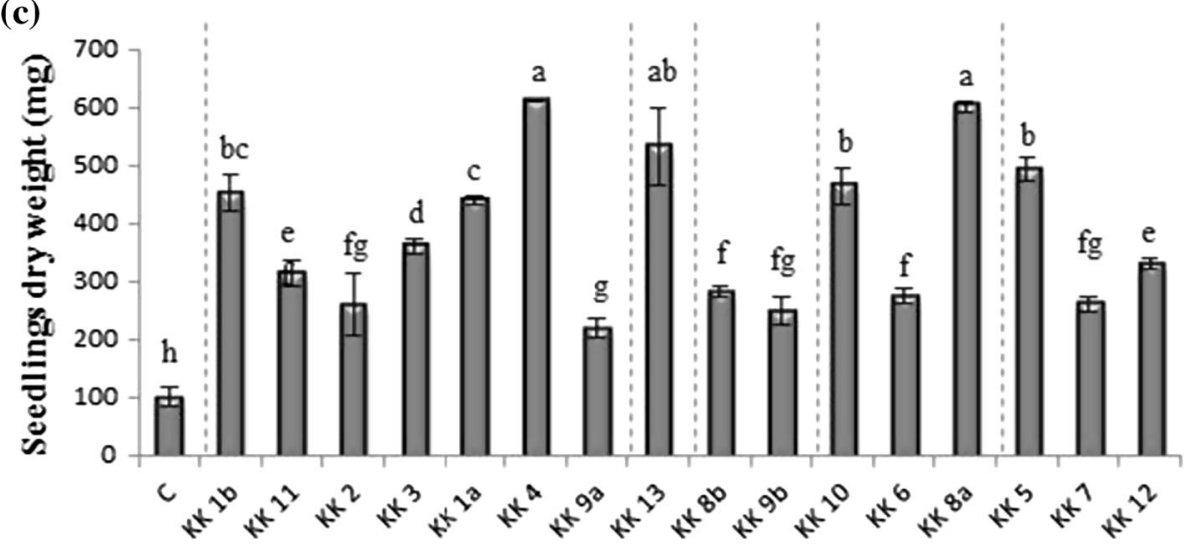

whole seedling weight doubled (the seedling dry weight was 2.4 times that of the seedlings treated with KK 9b) (Fig. 4c). Similarly, a beneficial effect on the seedlings growth involving the amount of indolic compounds produced by the bacteria was observed in two Enterobacteriaceae bacteria strains: $R$. planticola KK $8 \mathrm{a}$ and KK 6 closest relative to Leclercia adecarboxylata. To summarize, the ability of almost the all strains (except for $P$. brassicacearum KK 5) to enhance root growth (dry weight) was positively correlated with the indolic compounds production $(r=0.69 ; P=0.0001)$ (data not shown).
The ACCD activity in $R$. planticola KK 8 a and KK 6 closest relative to $L$. adecarboxylata was at a similar, very low, level $\left(0.42\right.$ and $0.45 \mu \mathrm{mol} \alpha-\mathrm{KB} \mathrm{mg}$ protein $\left.^{-1} \mathrm{~h}^{-1}\right)$, but KK 8a showed an about 1.6 times higher ability to produce indolic compounds $\left(41.1 \mu \mathrm{g} \mathrm{ml}^{-1}\right)$ than strain $\mathrm{KK}$ $6\left(25.7 \mu \mathrm{g} \mathrm{ml}^{-1}\right.$; Table 3$)$, and induced an about 1.4 and 1.9 times higher fresh weight of roots and shoots, respectively (Fig. 3o, n) the dry weight of roots, shoots, and whole seedlings being higher by the factor of 1.9, 2.4 and 2.2, respectively (Fig. 4a-c). A very interesting effect on seedling growth was observed after inoculation with 
Table 3 Indolic compounds production and ACC deaminase activity in bacteria isolated from Medicago sativa rhizosphere and nodules

\begin{tabular}{|c|c|c|c|}
\hline Families & Strain name & Indolic compounds $\left(\mu \mathrm{g} \mathrm{IAA} \mathrm{ml}{ }^{-1}\right)$ & $\operatorname{ACCD}\left(\mu \mathrm{mol} \alpha-\mathrm{KB}\right.$ mg protein $\left.{ }^{-1} \mathrm{~h}^{-1}\right)$ \\
\hline \multirow[t]{7}{*}{ Bacillaceae } & Bacillus niacini $\mathrm{KK} 1 \mathrm{~b}$ & $37.1 \pm 2.6^{\mathrm{bc}}$ & $0.6 \pm 0.01^{\mathrm{h}}$ \\
\hline & Bacillus megaterium KK 11 & $36.8 \pm 3.3^{\mathrm{bc}}$ & $345.3 \pm 49.2^{\mathrm{b}}$ \\
\hline & Lysinibacillus fusiformis $\mathrm{KK} 2$ & $32.9 \pm 2.4^{\mathrm{d}}$ & $3.1 \pm 0.1^{\mathrm{g}}$ \\
\hline & Lysinibacillus fusiformis KK 3 & $25.4 \pm 0.1^{\mathrm{e}}$ & $3.0 \pm 0.07^{\mathrm{g}}$ \\
\hline & Paenibacillus odorifer KK 1a & $34.5 \pm 2.3^{\mathrm{cd}}$ & $0.7 \pm 0.04^{\mathrm{h}}$ \\
\hline & Paenibacillus borealis KK 4 & $41.1 \pm 3.0^{\mathrm{b}}$ & $35.3 \pm 0.5^{\mathrm{d}}$ \\
\hline & Paenibacillus amylolyticus KK 9a & $29.7 \pm 4.9^{\text {cd }}$ & $21.6 \pm 0.9^{\mathrm{e}}$ \\
\hline Rhizobiaceae & Sinorhizobium meliloti KK 13 & $47.2 \pm 2.8^{\mathrm{a}}$ & n.d. \\
\hline \multirow[t]{2}{*}{ Xantomonadaceae } & Stenotrophomonas maltophilia $\mathrm{KK} 8 \mathrm{~b}$ & $35.4 \pm 0.8^{\mathrm{c}}$ & $5.6 \pm 0.1^{\mathrm{f}}$ \\
\hline & Stenotrophomonas maltophilia $\mathrm{KK} 9 \mathrm{~b}$ & $23.2 \pm 1.6^{\mathrm{ef}}$ & n.d. \\
\hline \multirow[t]{3}{*}{ Enterobacteriaceae } & Citrobacter murliniae KK 10 & $30.1 \pm 3.8^{\mathrm{cd}}$ & $3.3 \pm 0.04^{\mathrm{g}}$ \\
\hline & Leclercia adecarboxylata KK 6 & $25.7 \pm 2.1^{\mathrm{de}}$ & $0.5 \pm 0.01^{\mathrm{h}}$ \\
\hline & Raoultella planticola $\mathrm{KK} 8 \mathrm{a}$ & $41.1 \pm 2.0^{\mathrm{b}}$ & $0.4 \pm 0.01^{\mathrm{h}}$ \\
\hline \multirow[t]{3}{*}{ Pseudomonadaceae } & Pseudomonas brassicacearum KK 5 & $4.0 \pm 0.1^{\mathrm{g}}$ & $1469.2 \pm 136.6^{\mathrm{a}}$ \\
\hline & Pseudomonas corrugata KK 7 & $24.8 \pm 1.0^{\mathrm{e}}$ & $108.2 \pm 2.5^{\mathrm{c}}$ \\
\hline & Pseudomonas corrugata KK 12 & $46.8 \pm 1.9^{\mathrm{a}}$ & $34.6 \pm 1.2^{\mathrm{d}}$ \\
\hline
\end{tabular}

Two-way ANOVA with Duncan's multiple range test was used to detect significant differences. Means denoted with different letters (a-h) are significantly different $(P \leq 0.05)$

n.d. not detected

bacteria from two different species of the genus Paenibacillus: P. odorifer KK 1a (Fig. 3g) and P. borealis KK 4 (Fig. 3h). The amounts of indolic compounds produced by those bacteria did not differ much, but the strains differed strongly in their ACCD activity. In P. borealis KK 4, the ACCD activity was 52 times higher that of $P$. odorifer KK 1a (Table 3). However, the difference had no effect on the root weight (the fresh and dry weights were almost identical; Figs. 3g, h, 4b), but did affect the root architecture. Roots of the seedlings inoculated with $P$. borealis $\mathrm{KK} 4$ (Fig. 3h) were more branched. Also the shoot fresh weight was twice that of the shoot weight of seedlings pre-treated with P. odorifer KK 1 (Fig. 3g). An identical pattern was observed in the shoot dry weight (Fig. 4a). Generally, the ACCD activity did not correlated with the root dry weight (data not shown).

A very surprising result of seedling growth promotion by $P$. brassicacearum KK 5 (Fig. 3p) was observed with respect of the strain's ability to produce indolic compounds and its ACCD activity. Among all the 16 strains examined, the bacteria in question showed the lowest capacity for indolic compounds production $\left(4.0 \mu \mathrm{g} \mathrm{ml}^{-1}\right)$ and the highest ACCD activity $\left(1469.2 \mu \mathrm{mol} \alpha-\mathrm{KB} \mathrm{mg}\right.$ protein ${ }^{-1} \mathrm{~h}^{-1}$ ) (Table 3), but the 4-week-old seedlings inoculated with the bacterium showed a well-developed root architecture (Fig. 3p) and high dry weights of both shoot sand whole seedlings (Fig. 4b, c).

To find out whether our three Pseudomonas strains contain the phlD gene responsible for the synthesis of monoacetylphloroglucinol, the DAPG precursor, PCR amplification of DNAs was performed using primers specifically designed for the phlD gene. The presence of the gene fragment was confirmed for two (out of 3) Pseudomonas strains: P. brassicacearum KK 5 and $P$. corrugata KK 12 (Supplemental Fig. S1). Sequencing of the $p h l \mathrm{D}$ gene fragments from both strains confirmed the expected size of 720 bp. Moreover, as seen in Fig. 5, the similarity to other DAPG precursor genes from fluorescent pseudomonads group is evident.

\section{Biofertilizing potential of the bacteria}

Several tests were used to evaluate the potential of all the isolates to be used as biofertilizers. The ability of all the strains examined to convert insoluble inorganic phosphorus (P) and zinc ( $\mathrm{Zn}$ ) compounds, such as tricalcium phosphate and zinc oxide, to bioavailable forms was studied (Table 4). Six out of the 16 strains were not able to solubilize the insoluble inorganic $\mathrm{P}$ compounds. Three strains only ( $P$. brassicacearum $\mathrm{KK} 5, P$. corrugata $\mathrm{KK} 7, R$. planticola $\mathrm{KK} 8 \mathrm{a}$ ), when tested in vitro, formed clear halo zones around the colonies kept on Pikovskay'a agar media (high response), while the remaining 7 strains showed a very low P-solubilizing activity. On the other hand, half of the strains tested displayed the ability to dissolve the inorganic zinc compounds. Inorganic zinc oxide was solubilized by all the three Pseudomonadaceae and Enterobacteriaceae strains as well as by one strain each representing the Xantomonadaceae and the Bacillaceae. 
Fig. 5 Phylogenetic tree (not rooted) of 2,4-

diacetylophloroglucinol biosynthetic protein (PhlD) fragments of two strains (KK 5 and KK 12) inferred by the neighbor-joining method. Bootstraps of 1000 replicates were used and are indicated at the nodes. Scale bar indicates 0.005 changes/site

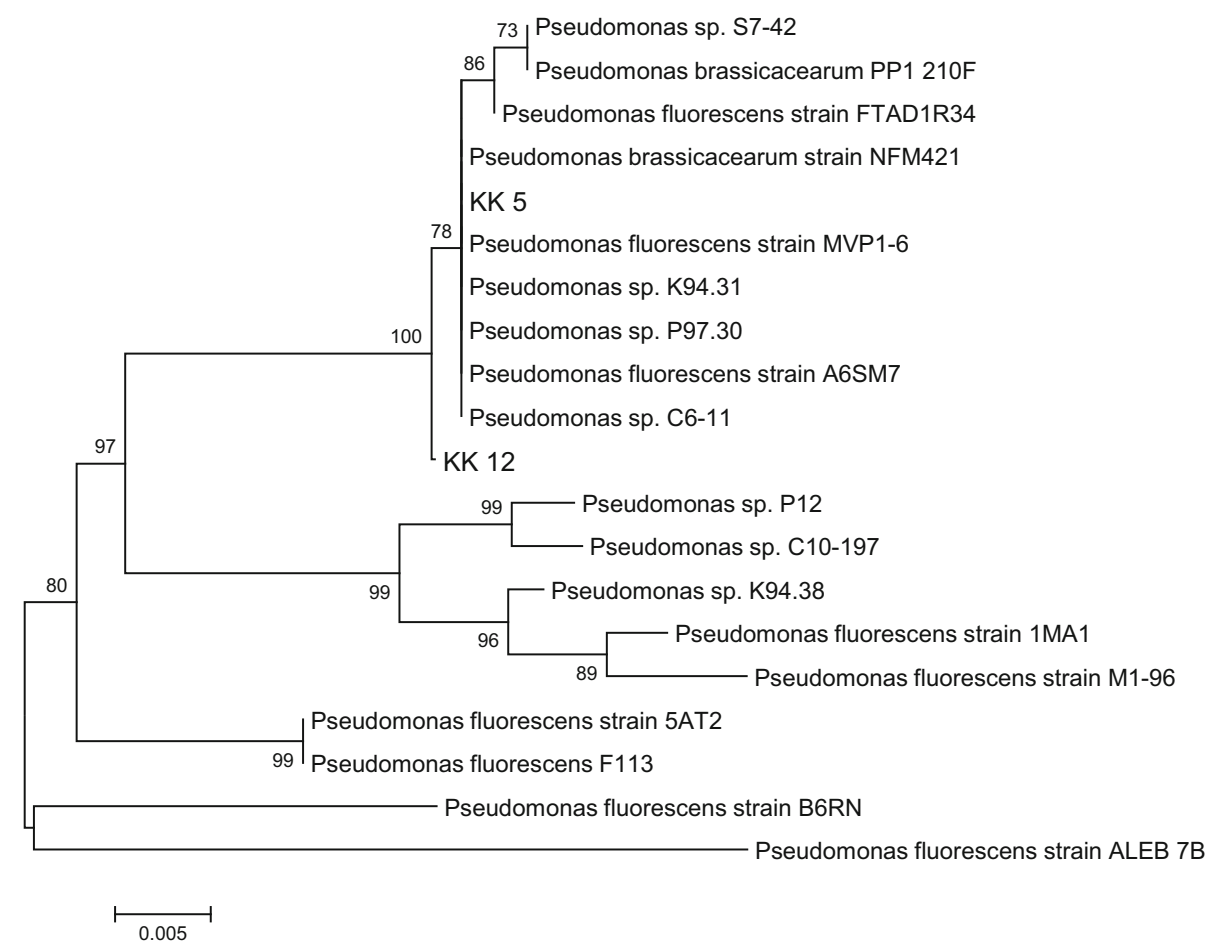

Thirteen out of 16 strains tested positive for the production of siderophores, iron chelating compounds, as evidenced by the yellow zone on the CAS agar medium. The effect occurred because of iron removal from the blue CASFE(III) complex during siderophore production. The most efficient siderophore producers were the following 5 strains: B. megaterium KK 11, P. brassicacearum KK 5, $P$. corrugata KK 7, KK 8b and KK 6 closest relative to $S$. maltophilia and L. adecarboxylata.

Ability for produce ammonia $\left(\mathrm{NH}_{3}\right)$ was a trait common to all the 16 strains (Table 4). Nessler's reaction used to detect ammonia emission by bacteria growing on peptone media showed the highest ammonia amount to have been produced by L. fusiformis KK 3 .

Six isolates (L. fusiformis KK 2, S. maltophilia KK 8b and KK 9b, R. planticola KK 8a, P. brassicacearum KK 5, $P$. corrugata KK 7 ) showed the ability to acidify TSA medium (Table 4).

\section{Inoculation with selected rhizobacteria increased the IAA content in M. truncatula leaves}

To investigate whether the inoculation with bacteria isolated from the rhizospere and nodules of $M$. sativa affects the IAA content in $M$. truncatula, we assayed IAA in leaves of inoculated and non-inoculated plants. For this experiment, we selected four strains. Three of them $(P$. borealis KK 4, S. meliloti KK 13 and $P$. brassicacearum KK 5) proved to be the most effective promoters of $M$. truncatula seedling development, whereas one ( $P$. corrugata KK 7) showed the weakest ability to promote the root and shoot growth (Fig. $3 \mathrm{~h}, \mathrm{j}, \mathrm{p}$, q). When selecting the strains as representative pseudomonads, their ability to produce indolic compounds, the ACCD activity and the presence of the phlD gene were taken into account (Table 3; Supplemental Fig. S1). The IAA amount in leaves of 5-week-old seedlings 3 days after soil inoculation with all the bacterial strains (Fig. 6) was observed to have increased. The highest increase was recorded after inoculation with $P$. brassicacearum KK 5, characterized by the lowest capacity for the production of indolic compounds and the highest ACCD activity (Table 3), and in which the phlD gene was detected (Supplemental Fig. S1). On the other hand, S. meliloti KK 13, the most efficient producer of indolic compounds but lacking the ACCD activity also increased the endogenous IAA content in the leaves, but the increase was lower than that induced by $P$. brassicacearum KK 5. After 7 days from inoculation of seedlings with all the strains discussed above, the endogenous IAA level in leaves was similar and higher than that in leaves of non-inoculated plants.

\section{Discussion}

Beneficial effects of PGPR on plant growth and yield of many agricultural crops have been shown by numerous studies (Hayat et al. 2010; Bhattacharyya and Jha 2012; 
Table 4 Some biochemical traits of bacteria isolated from Medicago sativa rhizosphere and nodules

\begin{tabular}{|c|c|c|c|c|c|c|}
\hline Families & Strain name & P-sol & $\begin{array}{l}\mathrm{Zn}- \\
\text { sol }\end{array}$ & $\begin{array}{l}\text { Siderophore } \\
\text { production }\end{array}$ & $\begin{array}{l}\mathrm{NH}_{3} \\
\text { production }\end{array}$ & $\begin{array}{l}\text { Acidification of } \\
\text { medium }\end{array}$ \\
\hline \multirow[t]{7}{*}{ Bacillaceae } & Bacillus niacini $\mathrm{KK} 1 \mathrm{~b}$ & - & + & - & + & - \\
\hline & Bacillus megaterium KK 11 & + & - & +++ & ++ & - \\
\hline & Lysinibacillus fusiformis KK 2 & + & - & - & ++ & - \\
\hline & Lysinibacillus fusiformis KK 3 & - & - & + & +++ & + \\
\hline & Paenibacillus odorifer KK 1a & + & - & - & + & - \\
\hline & Paenibacillus borealis KK 4 & + & - & + & + & - \\
\hline & Paenibacillus amylolyticus KK 9a & + & - & ++ & + & - \\
\hline Rhizobiaceae & Sinorhizobium meliloti KK 13 & + & - & + & ++ & - \\
\hline \multirow[t]{2}{*}{ Xantomonadaceae } & $\begin{array}{l}\text { Stenotrophomonas maltophilia } \mathrm{KK} \\
8 \mathrm{~b}\end{array}$ & - & - & +++ & + & + \\
\hline & $\begin{array}{l}\text { Stenotrophomonas maltophilia } \mathrm{KK} \\
9 \mathrm{~b}\end{array}$ & - & + & ++ & + & + \\
\hline \multirow[t]{3}{*}{ Enterobacteriaceae } & Citrobacter murliniae KK 10 & - & +++ & ++ & ++ & - \\
\hline & Leclercia adecarboxylata KK 6 & - & + & +++ & ++ & - \\
\hline & Raoultella planticola $\mathrm{KK} 8 \mathrm{a}$ & ++ & + & + & + & + \\
\hline \multirow[t]{3}{*}{ Pseudomonadaceae } & Pseudomonas brassicacearum KK 5 & +++ & +++ & +++ & ++ & + \\
\hline & Pseudomonas corrugata KK 7 & ++ & ++ & +++ & ++ & + \\
\hline & Pseudomonas corrugata KK 12 & + & + & ++ & + & - \\
\hline
\end{tabular}

Reaction index: - , negative; + , low; ++ , medium; +++ , high

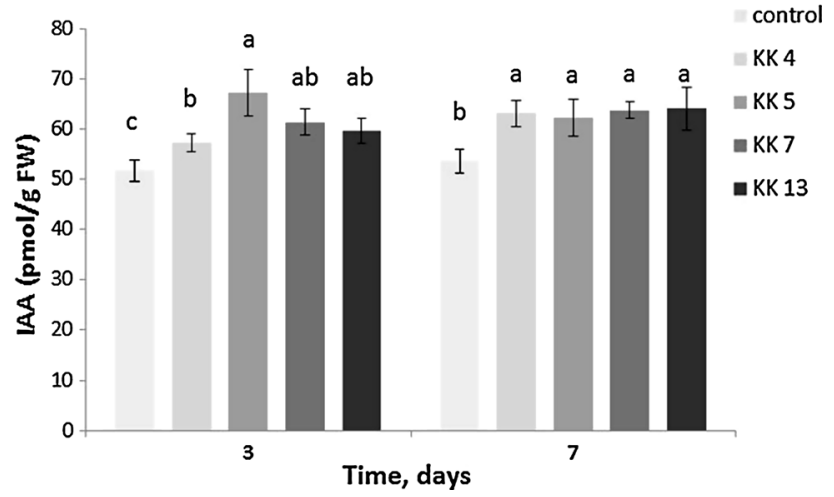

Fig. 6 IAA content in leaves of M. truncatula seedlings 3 and 7 days after soil inoculation of 5-week-old seedlings with Paenibacillus borealis KK 4, Pseudomonas brassicacearum KK 5, P. corrugata KK 7, Sinorhizobium melilotii KK 13. IAA content in leaves of 5-weekold non-inoculated control seedlings at $\mathrm{T}=0$ was $52.68 \pm 3.24 \mathrm{pmol} / \mathrm{g} \mathrm{FW}$

Glick 2012; Vacheron et al. 2013). However, to date no data have been published on the positive effects of PGPR isolated from the rhizosphere of $M$. sativa (alfalfa) and their application to promote the development of seedlings of M. truncatula (medic barrel). In this study, we isolated bacterial strains from the alfalfa rhizosphere, identified them and evaluated their potential as PGPR for $M$. truncatula.
Based on morphological, physiological and biochemical characteristics, 7 isolates could be pre-assigned to the families Bacillaceae and Listeriaceae, 9 isolates could be identified as representing the Pseudomonadaceae, Enterobacteriaceae, Moraxellaceae, Xantomonadaceae, Burkholderiaceae and Rhizobiaceae. However, by phylogenetic analysis of the 16S rRNA gene sequences it was found that the strains represented 5 rather than 8 families (Bacillaceae, Pseudomonadaceae, Enterobacteriaceae, Xantomonadaceae and Rhizobiaceae). Most strains (7) isolated from the alfalfa rhizosphere belonged to the Bacillaceae. Three strains each were assigned to the Pseudomonadaceae and Enterobacteriaceae, two to the Xantomonadaceae and one to the Rhizobiaceae. The Bacillaceae and Pseudomonadaceae species are common rhizospheric bacteria, and have been isolated from the rhizosphere of different agricultural crops, although there are few data on bacteria isolated from the Fabaceae rhizosphere. The literature contains data on the presence of the Bacilleaceae bacteria [B. megaterium strain B153-2-2, Bacillus fusiformis (PM-5)] in the soybean rhizosphere (Liu and Sinclair 1992; Park et al. 2005).

The species dealt with in this work have not been reported to be associated with the alfalfa rhizosphere before. Although there is admittedly some information about bacteria isolated from the alfalfa rhizosphere, the authors did not identify the bacteria isolates, but provided 
codes only (Bharucha et al. 2013a). Similarly, Bharucha et al. (2013b) reported a bacterium identified from the alfalfa rhizosphere, but provided the genus identification only (Bacillus sp.). Earlier, Guiñazú et al. (2010) also reported the isolation of bacteria from the alfalfa rhizosphere, but for molecular identification of these isolates they used a too short DNA region (318 bp) for precise taxonomic identification. The authors found the presence of strains assigned to the genera Pseudomonas and Bacillus.

The present work demonstrated, for the first time, that all the bacteria from the $M$. sativa rhizosphere identified could be effective in enhancing the $M$. truncatula seedling development in soil (sand and perlite mixture) under controlled growth room conditions. The main effects observed 4 weeks after inoculation of 1-week-old seedlings involved an increase in root fresh and dry weights as well as root branching.

A positive effect on shoot development was observed as well. Our results are in line with findings of many other workers who assessed effects of inoculation with nonpathogenic plant growth promoting bacteria (PGPR) on growth of many other plants (Glick 1995, 2012; Wissuwa et al. 2009; Martinez-Viveros et al. 2010; Rashid et al. 2011). Seven out of the 16 bacteria species examined proved to be most effective promoters of the $M$. truncatula seedling development. In terms of the seedling fresh and dry weight, those bacteria may be arranged in the following order: P. borealis KK 4 (Bacillaceae), R. planticola KK $8 \mathrm{a}$ (Enterobacteriaceae), S. meliloti KK 13 (Rhizobiaceae), $P$. brassicacearum KK 5 (Pseudomonadaceae), C. murliniae KK 10 (Enterobacteriaceae), B. niacini KK 1b (Bacillaceae) and $P$. odorifer KK 1a (Bacillaceae).

The approach used in this study included screening of the isolated bacteria for their in vitro indolic compounds biosynthesis and ACCD activity. The production of phytohormones, including auxins, by PGPR is now considered to be one of the most important direct mechanisms by which many rhizobacteria promote plant growth (Spaepen et al. 2007; Spaepen and Vanderleyden 2011; Glick 2012). Among indolic compounds, IAA is mainly known as an inducer of lateral and adventitious root formation (Casimiro et al. 2001; Sorin et al. 2005). Indolic compounds were produced, in the presence of its precursor L-tryptophan $\left(500 \mu \mathrm{g} \mathrm{ml}^{-1}\right)$, by all the 16 isolates from the $M$. sativa rhizosphere. Production of these compounds was quantified as ranging from 4.0 to $47.2 \mu \mathrm{g} \mathrm{ml}^{-1}$. In the presence of tryptophan $(1 \%)$, bacterial strains representing three genera: Pseudomonas, Bacillus and Azospirillum produced IAA in amounts ranging from 1.2 to $44.4 \mu \mathrm{g} \mathrm{ml}^{-1}$, but the production was negatively correlated with the root length, while correlating positively with the number of roots in 15-day-old wheat seedlings (Hussain and Hasnain 2011). Our results may suggest that indolic compounds production by bacterial strains, except that by $P$. brassicacearum $\mathrm{KK} 5$, can be responsible for stimulation of $M$. truncatula root development; the indolic compounds content was positively correlated with the root dry mass $(r=0.69 ; P=0.0001)$. P. borealis KK 4, R. planticola KK 8a, S. meliloti KK 13, C. murliniae KK 10, B. niacini $\mathrm{KK} 1 \mathrm{~b}$ and $P$. odorifer $\mathrm{KK} 1 \mathrm{a}$, which promoted root growth most effectively, are characterized by the highest capacity for indolic compounds production in the presence of tryptophan, the plant IAA precursor. Indolic compounds production by these strains ranged from about 30-47 $\mu \mathrm{g} \mathrm{ml}^{-1}$. That indolic compounds are mainly responsible for the stimulation of $M$. truncatula seedling growth can be clearly seen when comparing effects of two bacterial strains: $S$. meliloti KK 13 (Rhizobiaceae) and $S$. maltophilia KK 9b (Xantomonadaceae). Showing no deaminase activity, they differ in the ability to produce indolic compounds; KK 13 which produced 2 times more these compounds $\left(47.2 \mu \mathrm{g} \mathrm{ml}^{-1}\right)$ than $\mathrm{KK} \quad 9 \mathrm{~b}$ (23.3 $\left.\mu \mathrm{g} \mathrm{ml}^{-1}\right)$ was more effective in stimulating the roots mass and branching, and the shoot and seedling weight. A positive correlation between auxin production and growth promoting activity of diverse PGPR has been also reported in Brassica juncea, wheat and soya bean (Asghar et al. 2002; Khalid et al. 2004; Wahyudi et al. 2011).

To date, however, no information about such correlations in M. truncatula under in vivo conditions is available. Earlier Nolan et al. (2003) showed that when M. truncatula leaf explant tissues were cultured in vitro in an auxincontaining medium, they produced numerous roots. However, our study did not always demonstrate such a positive correlation between high levels of bacterial indolic compounds and root development. When the M. truncatula seedlings were inoculated with $P$. brassicacearum KK 5, it proved markedly effective in promoting root system development (particularly the lateral roots), but was one of the lowest indolic compounds producers (as little as $4 \mu \mathrm{g} \mathrm{ml}^{-1}$ ). The promotional activity of this bacteria on the root architecture resulted from a mechanism other than the bacterial indolic compounds. Some strains of fluorescent pseudomonads are known to produce a secondary metabolite, 2,4-diacetylphloroglucinol (DAPG) (Dwivedi and Johri 2003). DAPG can be a signal molecule for plants, as enhancement of root branching in tomato and wheat seedlings has been reported (Brazelton et al. 2008; Couillerot et al. 2011). Application of exogenous DAPG can alter the root architecture of tomato seedlings by interacting with an auxin-dependent signaling pathway (Brazelton et al. 2008; Couillerot et al. 2011). These authors observed also that roots of the auxin-resistant diageotropica tomato mutant showed a reduced DAPG sensitivity with regard to the inhibition of the primary root growth and induction of root branching. 
In the present study, we used electrophoresis of the PCR products amplified from DNA of three Pseudomonas strains with primers for the $p h l \mathrm{D}$ gene responsible for the synthesis of monoacethylphloroglucinol (MAPG), the DAPG precursor. The detection of the phlD gene in $P$. brassicacearum KK 5, and also in P. corrugata KK 12, could suggest DAPG production by these bacteria and probably their potential contribution to the observed strong stimulation of root branching in M. truncatula seedlings. However, to verify this hypothesis, DAPG quantification has to be performed, and phlD mutants should be generated.

The PGPR which do not produce auxins are also known for their ability to modify the endogenous plant IAA transport or for regulation of auxin homeostasis by, e.g., production of volatile organic compounds (VOC), resulting in the same root architecture effects (Zhang et al. 2007; Contesto et al. 2010; Zamioudis et al. 2013). Our results suggest that endogenous plant IAA, the content of which in seedling leaves increased after 3 and 7 days following soil inoculation with rhizobacteria, may be probably involved in $M$. truncatula seedling growth promotion. Thus, we provide evidence that some PGPR strains can trigger an increase of the endogenous auxin content in leaves, the main site of auxin production. Contesto et al. (2010) showed that up-regulation of several genes involved in tryptophan and IAA biosynthesis took place in shoots of 12-day-old A. thaliana seedlings inoculated with Phyllobacterium brassicacearum STM196. Consistent with the increased expression levels of genes involved in tryptophan biosynthesis, the inoculated shoots contained higher amounts $(80 \%)$ of this IAA precursor compared to the non-inoculated shoots. However, the IAA level in Arabidopsis shoots remained essentially unchanged upon inoculation with the strain in question.

Numerous studies have suggested that bacterial IAA and ACCD synergistically promote plant growth (Glick et al. 2007; Glick 2012). The main visible effect of root inoculation with ACCD-producing bacteria is the enhancement of plant root elongation. Patten and Glick (2002) suggested that IAA and ACCD work in concert to stimulate root elongation. Exogenous IAA is known to increase transcription and activity of ACC synthase (Peck and Kende 1995), an enzyme which catalyzes the ACC synthesis in peas. The plant ACC stimulates ACCD activity in bacteria (Li and Glick 2001). An activity of $20 \mathrm{nmol} \alpha-\mathrm{KB} \mathrm{mg}$ protein $^{-1} \mathrm{~h}^{-1}$ has been reported (Penrose and Glick 2003) to be sufficient for plant growth promotion. In our study the 16 strains for which the ACC-containing selection medium was used as the sole nitrogen source, 14 showed the ACCD activity to range from 0.2 to about $1469.2 \mu \mathrm{mol} \alpha-\mathrm{KB} \mathrm{mg}$ protein ${ }^{-1} \mathrm{~h}^{-1}$. It appears that some of the $M$. sativa rhizosphere strains analyzed in this study could be among the potentially $M$. truncatula growth promoting bacteria. However, our results show that indolic compounds production by most of the strains isolated from the $M$. sativa rhizosphere, rather than the ACCD activity, is responsible mainly for stimulating $M$. truncatula seedling development (roots and shoots). No correlation between the ACCD activity and the root dry mass of roots was observed. In general, the highest $M$. truncatula seedling growth promotion was obtained after inoculation with strains which produced most of the IAA (between 30 and $47 \mu \mathrm{g} \mathrm{ml}^{-1}$ ), with simultaneous absence or very low activity of ACCD. Previously, we also suggested that IAA production rather than ACCD activity in two Agrobacterium rhizogenes strains, 15834 and LBA1334, might be responsible for the stimulation of the grass Festuca rubra L. seed germination, seedling emergence and development upon seed inoculation; mainly by increasing growth of lateral roots and more complex architecture of the branching root system (Król et al. 2014). We compared the effects of seed inoculation of the two strains tested with the ability to produce IAA and of exogenous application of IAA at concentrations corresponding to IAA production by these strains. The presence of exogenous IAA during seed treatment produced a stimulatory effect on seedlings growth, but the effect was lower compared to that of a treatment with bacterial strains. Improvement of $F$. rubra L. seedling development, particularly visible in the root architecture, is achieved because the two bacteria strains are able to produce IAA and have active ACCD which probably prevents the root growth-inhibiting levels of ethylene induced by bacterial or exogenous IAA. However, the exact mechanism of growth stimulation by bacteria is still unclear. This is distinctly visible on the example of the $P$. brassicacearum $\mathrm{KK} 5$, a strain that is an excellent promoter of $M$. truncatula seedling growth: the strain exerted a particularly positive effect on the root system development, but was also least able to produce IAA (only $4 \mu \mathrm{g} \mathrm{ml}^{-1}$ ) among the strains examined, and was characterized by the highest ACCD activity (up to $1467 \mu \mathrm{mol} \alpha$ $\mathrm{KB}$ mg protein ${ }^{-1} \mathrm{~h}^{-1}$ ). However, Contesto et al. (2008) described that the effects of the acds-deficient mutants of Phyllobacterium brassicacearum STM196, P. putida UW4, Rhizobium leguminosarum bv. viciae 128C53K and Mesorhizobium loti MAFF303099 on the root system architecture of Arabidopsis seedlings were not significantly different from those of their wild-type counterparts. The only exception found concerned the acdS mutant of $P$. putida UW4 which triggered an increase in lateral root number, as opposed to the WT strain which did not affect this number. In turn, $P$. brassicacearum strain Am3 producing ACCD (ca. $10 \mu \mathrm{mol} \alpha-\mathrm{KB} \mathrm{mg} \mathrm{protein}{ }^{-1} \mathrm{~h}^{-1}$ ) showed both pathogenic and growth promoting properties in its interaction with tomato seedlings (Belimov et al. 
2007), depending on the density of the inoculant used. At a low bacterial concentration $\left(10^{6}\right.$ cells $\left.\mathrm{ml}^{-1}\right)$, increased in vitro root elongation and root biomass of soil-grown tomato were recorded; however, a higher concentration of the strain mentioned produced a negative effect on root elongation. The ACCD-deficient mutant of strain Am3 (T8) decreased root elongation and biomass production, compared to the wild-type Am3. In our experiments, the density of $P$. brassicacearum KK5 inoculant was high $\left(10^{8}\right.$ cells $\mathrm{ml}^{-1}$ ) and positive effects on root and seedling development were observed. Similarly, it was found earlier that $P$. brassicacearum Am3 increased rape and pea plant growth in pot experiments when the plants were inoculated with a high density suspension $\left(5 \times 10^{7}\right.$ cells $\left.\mathrm{ml}^{-1}\right)$ (Safronova et al. 2006). Thus, it is becoming increasingly apparent that each rhizobacterium can promote plant growth by several mechanisms. In the case of $M$. truncatula seedlings and $P$. brassicacearum KK 5, a low level of bacterial indolic compounds $\left(4 \mu \mathrm{g} \mathrm{ml}^{-1}\right)$, a high ACCD activity $\left(1467 \mu \mathrm{mol} \alpha-\mathrm{KB} \mathrm{mg}\right.$ protein $\left.{ }^{-1} \mathrm{~h}^{-1}\right)$, the presence of $p h l \mathrm{D}$ gene responsible for biosynthesis of the DAPG precursor and an increase in endogenous levels of IAA in leaves may probably be involved in promoting the development of seedlings. There is clear evidence that plant growth promotion by rhizobacteria involves more mechanisms than one.

Moreover, PGPR can additionally help plants by increasing their uptake of nutrient elements such as $\mathrm{P}$ and $\mathrm{Zn}$ on account of their ability to solubilize the unavailable nutrient forms, which is one of the essential criteria in facilitating the transport of most nutrients, including $\mathrm{P}$ and $\mathrm{Zn}$ (Wissuwa et al. 2009). The low availability of macronutrient $\mathrm{P}$ to plants results from the fact that the vast majority of soil $\mathrm{P}$ is in insoluble forms (both organic and inorganic), and plants can only absorb $\mathrm{P}$ in two soluble forms: the monobasic $\left(\mathrm{H}_{2} \mathrm{PO}_{4}^{-}\right)$and the diabasic $\left(\mathrm{HPO}_{4}^{2-}\right)$ ions. Strains representing the genera Pseudomonas, Bacillus and Rhizobium are among the most powerful phosphate solubilizers (Richardson et al. 2009; Hayat et al. 2010). In our study, all the three Pseudomonas strains were capable of solubilizing the insoluble tri-calcium phosphate $\left[\mathrm{Ca}_{3}\left(\mathrm{PO}_{4}\right)_{2}\right], P$. brassicacearum KK 5 showing the highest solubilizing ability. Five of the seven Bacillaceae strains were characterized by a low ability to solubilize this compound in question. Jorquera et al. (2008) isolated P-solubilizing bacteria from the rhizospheres of the cultivated Fabaceae plants such as Trifolium repens and Lupinus luteus. Cattelan et al. (1999) found only two of five rhizospheric isolates that tested positive for solubilization had actually a positive effect on soybean seedling growth. In earlier studies, phosphate $(\mathrm{P})$-solubilizing bacteria such as Bacillus and Paenibacillus sp. were applied to soils to enhance the phosphorus status of plants (Van Veen et al. 1997). Thus, it is likely that many of the so-called biofertilizers exert a dual effect that is mediated by direct solubilization of inorganic $\mathrm{P}$ by organic acids synthesized and excreted by soil bacteria, mineralization of organic $\mathrm{P}$ carried out by phosphohydrolases such as acid phosphatases, and a stimulatory effect by IAA production (Khan et al. 2009). It has been suggested that PGPR which decrease the medium $\mathrm{pH}$ during growth through their ability to produce organic acids are efficient $\mathrm{P}$ solubilizers (Nautiyal et al. 2000). Seven out of the 16 isolates from the alfalfa rhizosphere were able to acidify the TSA medium. Three of these were representatives of the Pseudomonadaceae (KK 5 , KK 7, KK 12), two were members of the Xantomonadaceae (KK 8b, KK 9b) and one each belonged to the Enterobacteriaceae (KK 8a) and Bacillaceae (KK 3).

In addition, some of the bacteria examined can help to increase the micronutrient ( $\mathrm{Zn}$ ) supply by solubilizing inorganic zinc compounds (Wissuwa et al. 2009). Among the strains tested, those representing the Enterobacteriaceae and Pseudomonadaceae showed the highest $\mathrm{ZnO}$ dissolving potential.

Iron, essential for cellular growth and metabolism, has-like phosphorus-a low mobility and is not easily available to plants, but may be supplied by bacteria. Many plants are known to use various bacterial siderophores as an iron source, although the total concentrations are probably too low to contribute substantially to plant iron uptake (Martinez-Viveros et al. 2010). Siderophores, as iron Fe-chelating agents, are produced by various types of bacteria including the Gram-negative Pseudomonas and Gram-positive Bacillus (Bhattacharyya and Jha 2012). In our experiments, all the strains isolated from the alfalfa rhizosphere did produce siderophores which were detected using the chrome azurol S assay, a general test for siderophores. The most positive reaction in this test was shown by the bacteria representing the genera Pseudomonas, Bacillus, Xanthomonas and Enterobacter.

Ammonia $\left(\mathrm{NH}_{3}\right)$ produced by rhizobacteria is an additional $\mathrm{N}$ source in soil (McNeill and Unkovich 2007). All the bacteria from the $M$. sativa rhizosphere were able to produce $\mathrm{NH}_{3}$ under in vitro condition in the presence of peptone. Fourteen strains are also potential ammonia producers because of the presence of ACCD which degrades ACC to ammonia and $\alpha$ ketobutyrate. When ammonia accumulates in the plant cells at levels higher than $0.1 \mathrm{mM}$, it can inhibit some processes such as seed germination and seedling establishment, but it can also stimulate root branching. So the beneficial effect of $P$. brassicacearum KK 5 observed is likely to be additionally related to the very high activity of ACCD in ammonia production. All these attributes of the bacteria examined may affect the nutrient uptake abilities of $M$. truncatula. 
This study illustrates the significance of screening the rhizobacteria under in vitro conditions for multiple PGPR traits and their evaluation under controlled conditions in pot experiments. The results obtained have led to the selection of effective PGPR isolates representing 5 families (Bacillaceae, Rhizobiaceae, Xantomonadaceae, Enterobacteriaceae, Pseudomonadaceae) which-as a result of their multiple PGPR traits-could prove effective in improving the seedling development of $M$. truncatula, a molecular model crop plant. Screening strategies for selecting the best strains will require more comprehensive knowledge on beneficial effects of the rhizobacteria on growth and development of roots, which is of a critical for effective soil exploration and access to nutrients. M. truncatula is a good molecular model which allow root traits to be more readily identified and manipulated, and makes it possible to find molecular markers for specific root traits and identification of genes involved in root development. All the 16 strains identified from the rhizosphere of $M$. sativa and particularly 6 of them (P. borealis KK $4, R$. planticola KK 8a, S. meliloti KK 13, P. brassicacearum KK 5, C. murliniae KK 10 and B. niacini KK 1b) appear to be interesting candidates, since inoculations with all these strains was found to affect the root architecture in $M$. truncatula.

Thus, it is becoming increasingly apparent that most PGPR strains can promote plant growth by several mechanisms, although most studies currently focus on individual mechanisms and have not yet been able to sort out the relative contribution of different processes responsible for successful plant growth promotion.

Author contribution statement EK initiated and designed research, interpreted the results and wrote the manuscript. AK conducted experiments and statistical analysis. Both authors approved the manuscript.

Acknowledgments This work was supported by the National Scientific Centre (NCN) Grant No. NN310784140. We are indebted to Dr. Teresa Radziejewska for linguistic assistance.

Open Access This article is distributed under the terms of the Creative Commons Attribution 4.0 International License (http://crea tivecommons.org/licenses/by/4.0/), which permits unrestricted use, distribution, and reproduction in any medium, provided you give appropriate credit to the original author(s) and the source, provide a link to the Creative Commons license, and indicate if changes were made.

\section{References}

Abberton M (2010) Enhancing the role of legumes: potential and obstacles. In: Abberton M, Conant R, Batello C (eds) Integrated crop management, vol. 11: Grassland, carbon sequestration: management, policy and economics. Proc Workshop on the role of grassland carbon sequestration in the mitigation of climate change, Rome, pp 177-187

Alexander DB, Zuberer DA (1991) Use of chrome azurol S reagents to evaluate siderophore production by rhizosphere bacteria. Biol Fertil Soils 12:39-45

Asghar HN, Zahir ZA, Arshad M, Khaliq A (2002) Relationship between in vitro production of auxins by rhizobacteria and their growth- promoting activities in Brassica juncea L. Biol Fertil Soils 35:231-237

Barker DG, Bianchi S, Blondon F, Dattee Y, Duc G, Essad S, Flament P, Philippe G, Génier G, Guy P, Muel X, Tourneur J, Dénarié J, Huguet $\mathrm{T}$ (1990) Medicago truncatula, a model plant for studying the molecular genetics of the Rhizobium-legume symbiosis. Plant Mol Biol Rep 8:40-49

Belimov AA, Dodd IC, Safronova VI, Hontzeas N, Davies WJ (2007) Pseudomonas brassicacearum strain Am 3 containing 1-aminocyclopropane-1-carboxylate deaminase can show both pathogenic and growth-promoting properties in its interaction with tomato. J Exp Bot 58:1485-1495

Bharucha UD, Patel KC, Trivedi UB (2013a) In vitro screening of isolates for the plant growth promotion activities from the rhizosphere of Alfalfa (Medicago sativa). J Microbiol Biotech Res 3:79-88

Bharucha UD, Patel KC, Trivedi UB (2013b) Antifungal activity of catecholate type siderophore by Bacillus sp. Int J Res Pharm Sci $4: 528-531$

Bhattacharyya PN, Jha DK (2012) Plant growth-promoting rhizobacteria (PGPR): emergence in agriculture. World J Microbiol Biotechnol 28:1327-1350

Bradford MM (1976) A rapid and sensitive method for the quantification of microgram quantities of protein utilizing the principle of protein-dye binding. Anal Biochem 72:248-254

Brazelton JN, Pfeufer EE, Sweat TA, Gardener BB, Coenen C (2008) 2,4-diacetylphloroglucinol alters plant root development. Mol Plant Microbe Interact 21:1349-1358

Cappuccino JC, Sherman N (1992) Microbiology: a laboratory manual, 3rd edn. Benjamin/Cummings Publ, New York, pp 125-179

Casimiro I, Marchant A, Bhalerao RP, Beeckman T, Dhooge S, Swarup R, Graham N, Inzé D, Sandberg G, Casero PJ, Bennett M (2001) Auxin transport promotes Arabidopsis lateral root initiation. Plant Cell 13:843-852

Cattelan AJ, Hartel PG, Fuhrmann JJ (1999) Screening of plant growth promoting rhizobacteria to promote early soybean growth. Soil Sci Soc Am J 63:1670-1680

Chandler D, Davidson G, Grant WP, Greaves J, Tatchell GM (2008) Microbial biopesticides for integrated crop management: an assessment of environmental and regulatory sustainability. Trends Food Sci Tech 19:275-283

Cladera AM, Bennasar AB, Barceló M, Lalucat J, García-Valdés E (2004) Comparative genetic diversity of Pseudomonas stutzeri genomovars, clonal structure, and phylogeny of the species. J Bacteriol 16:5239-5248

Contesto C, Desbrosses G, Lefoulon C, Béna G, Borel F, Galland M, Gamet L, Varoquaux F, Touraine B (2008) Effects of rhizobacterial ACC deaminase activity on Arabidopsis indicate that ethylene mediates local root responses to plant growth-promoting rhizobacteria. Plant Sci 175:178-189

Contesto C, Milesi S, Mantelin S, Zancarini A, Desbrosses G, Varoquaux F, Bellini C, Kowalczyk M, Touraine B (2010) The auxin-signaling pathway is required for the lateral root response of Arabidopsis to the rhizobacterium Phyllobacterium brassicacearum. Planta 232:1455-1470

Cook DR (1999) Medicago truncatula-a model in the making! Curr Opin Plant Biol 2:301-304 
Couillerot O, Combes-Meynet E, Pothier JF, Bellvert F, Challita E, Poirier MA, Rohr R, Comte G, Moënne-Loccoz Y, PrigentCombaret C (2011) The role of the antimicrobial compound 2,4diacetylphloroglucinol in the impact of biocontrol Pseudomonas fluorescens F113 on Azospirillum brasilense phytostimulators. Microbiology 157:1694-1705

DuPree MR, Wilcox G (1977) Bromothymol blue and carbohydratesensitive plating media. J Clin Microbiol 6:343-347

Dwivedi D, Johri BN (2003) Antifungals from fluorescent pseudomonads: biosynthesis and regulation. Curr Sci 85:1693-1703

Dworkin M, Foster J (1958) Experiments with some microorganisms which utilize ethane an hydrogen. J Bacteriol 75:592-603

Felsenstein J (1985) Confidence limits on phylogenies: an approach using the bootstrap. Evolution 39:783-791

Floková K, Tarkowská D, Miersch O, Strand M, Wasternack C, Novák O (2014) UHPLC-MS/MS based target profiling of stressinduced phytohormones. Phytochemistry 105:147-157

Gholami A, Shashsavani S, Nezarat S (2009) The effect of plant growth promoting rhizobacteria (PGPR) on germination, seedling growth and yield of maize. World Acad Sci Eng Technol 49:19-24

Gholami A, De Geyter N, Pollier J, Goormachtig S, Goossens A (2014) Natural product biosynthesis in Medicago species. Nat Prod Rep 31:356-380

Glick BR (1995) The enhancement of plant growth by free-living bacteria. Can J Microb 41:109-117

Glick BR (2012) Plant growth-promoting bacteria: mechanisms and applications. Scientifica. doi:10.6064/2012/963401

Glick BR, Cheng Z, Czarny J, Duan J (2007) Promotion of plant growth by ACC deaminase-producing soil bacteria. Eur J Plant Pathol 119:329-339

Graham PH, Vance CP (2003) Legumes importance and constraints to greater use. Plant Physiol 131:872-877

Guiñazú LB, Andrés JA, Del Papa MF, Pistorio M, Rosas SB (2010) Response of alfalfa (Medicago sativa L.) to single and mixed inoculation with phosphate-solubilizing bacteria and Sinorhizobium meliloti. Biol Fertil Soils 46:185-190

Hayat R, Ali S, Amara U, Khalid R, Ahmed I (2010) Soil beneficial bacteria and their role in plant growth promotion: a review. Ann Microbiol 60:579-598

Hohnjec N, Henckel K, Bekel T, Gouzy J, Dondrup M, Goesmann A, Küster H (2006) Transcriptional snapshots provide insights into the molecular basis of arbuscular mycorhiza in the model legume Medicago truncatula. Funct Plant Biol 33:737-748

Holt JG, Kreig NR, Sneath PHA, Staley JT, Wiliams ST (1994) Bergey's manual of determinative bacteriology. Williams and Wilkins, Maryland

Honma M, Shimomura T (1978) Metabolism of 1-aminocyclopropane-1-carboxylic acid. Agric Biol Chem 42:1825-1831

Hussain A, Hasnain S (2011) Interactions of bacterial cytokinins and IAA in the rhizosphere may alter phytostimulatory efficiency of rhizobacteria. World J Microbiol Biotechnol 27:2645-2654

Jorquera MA, Hernández MT, Rengel Z, Marschner P, de la Luz Mora M (2008) Isolation of culturable phosphobacteria with both phytate-mineralization and phosphate-solubilization activity from the rhizosphere of plants grown in a volcanic soil. Biol Fertil Soils 44:1025-1034

Khalid A, Arshad M, Zahir ZA (2004) Screening plant growthpromoting rhizobacteria for improving growth and yield of wheat. J Appl Microbiol 96:473-480

Khan AA, Miura H, Prusiński J, Ilyas S (1990) Matriconditioning of seeds to improve emergence. In: Proceedings of national symposium stand establishment horticultural crops, Minneapolis, pp 19-40

Khan AA, Jilani G, Akhtar MS, Naqvi SMS, Rasheed M (2009) Phosphorus solublizing bacteria: occurrence, mechanism and their role in crop production. J Agric Biol Sci 1:48-58
Król P, Adamska J, Kępczyńska E (2014) Enhancement of Festuca rubra L. germination and seedling growth by seed treatment with pathogenic Agrobacterium rhizogenes. Acta Physiol Plant 36:3263-3274

Li J, Glick BR (2001) Transcriptional regulation of the Enterobacter cloacae UW 1-aminocyclopropane-1-carboxylate (ACC) deaminase gene (acdS). Can J Microbiol 47:359-367

Liu ZL, Sinclair JB (1992) Population dynamics of Bacillus megaterium strain B153-2-2 in the rhizosphere of soybean. Phytopathology 82:1297-1301

Mantelin S, Touraine B (2004) Plant growth-promoting bacteria and nitrate availability: impacts on root development and nitrate uptake. J Exp Bot 55:27-34

Mantelin S, Desbrosses G, Larcher M, Tranbarger TJ, Cleyet-Marel J-C, Touraine B (2006) Nitrate-dependent control of root architecture and $\mathrm{N}$ nutrition are altered by a plant growthpromoting Phyllobacterium sp. Planta 223:591-603

Martinez-Viveros O, Jourquera MA, Crowley DE, Gajardo G, Mora ML (2010) Mechanisms and practical considerations involved in plant growth promotion by rhizobacteria. J Soil Sci Plant Nutr 10:293-319

McNeill A, Unkovich M (2007) The nitrogen cycle in terrestrial ecosystems. In: Marschner P, Rengel Z (eds) Nutrient cycling in terrestial ecosystems. Springer-Verlag, Berlin Heidelberg, pp 37-64

Nautiyal CS, Bhadauria S, Kumar P, Lal H, Mondal R, Verma D (2000) Stress induced phosphate solubilization in bacteria isolated from alkaline soils. FEMS Microbiol Lett 182:291-296

Nolan KE, Irwanto RR, Rose RJ (2003) Auxin up-regulates MtSERK1 expression in both Medicago truncatula root-forming and embryogenic cultures. Plant Physiol 133:218-230

Novák O, Hényková E, Sairanen I, Kowalczyk M, Pospišil T, Ljung K (2012) Tissue specific profiling of the Arabidopsis thaliana auxin metabolome. Plant J 72:523-536

Park M, Kim C, Yang J, Lee H, Shin W, Kim S, Sa T (2005) Isolation and characterization of diazotrophic growth promoting bacteria from rhizosphere of agricultural crops of Korea. Microbiol Res 160:127-133

Patten CL, Glick BR (2002) Role of Pseudomonas putida indoleacetic acid in development of the host plant root system. Appl Environ Microbiol 68:3795-3801

Peck SC, Kende H (1995) Sequential induction of the ethylene biosynthetic enzymes by indole-3-acetic acid in etiolated peas. Plant Mol Biol 28:293-301

Penrose DM, Glick BR (2003) Methods for isolating and characterizing ACC deaminase-containing plant growth-promoting rhizobacteria. Physiol Plant 118:10-15

Pikovskaya RI (1948) Mobilization of phosphorus in soil in connection with the vital activity of some microbial species. Mikrobiologiya 17:362-370

Raaijmakers JM, Weller DM, Thomashow LS (1997) Frequency of antibiotic-producing Pseudomonas spp. in natural environments. Appl Environ Microbiol 63:881-887

Rashid S, Charles TC, Glick BR (2011) Isolation and characterization of new plant growth-promoting bacterial endophytes. Appl Soil Ecol 61:217-224

Richardson AE, Barea J-M, McNeill AM, Prigent-Combaret C (2009) Acquisition of phosphorus and nitrogen in the rhizosphere and plant growth promotion by microorganisms. Plant Soil 321:305-339

Rose RJ (2008) Medicago truncatula as a model for understanding plant interactions with other organisms, plant development and stress biology: past, present and future. Funct Plant Biol 35:253-264

Safronova VI, Stepanok VV, Engqvist GL, Alekseyev YV, Belimov AA (2006) Root-associated bacteria containing 1-aminocyclopropane-1-carboxylate deaminase improve growth and nutrient 
uptake by pea genotypes cultivated in cadmium supplemented soil. Biol Fert Soils 42:267-272

Saitou N, Nei M (1987) The neighbor-joining method: a new method for reconstructing phylogenetic trees. Mol Biol Evol 4:406-425

Schwyn B, Neilands JB (1987) Universal chemical assay for the detection and determination of siderophores. Anal Biochem 160:47-56

Shokri D, Emtiazi G (2010) Indole-3-acetic acid (IAA) production in symbiotic and non-symbiotic nitrogen-fixing bacteria and its optimization by Taguchi design. Curr Microbiol 61:217-225

Sorin C, Bussell JD, Camus I, Ljung K, Kowalczyk M, Geiss G, McKhann H, Garcion C, Vaucheret H, Sandberg G, Bellini C (2005) Auxin and light control of adventitious rooting in Arabidopsis require ARGONAUTE1. Plant Cell 17:1343-1359

Spaepen S, Vanderleyden J (2011) Auxin and plant-microbe interactions. Cold Spring Harb Perspect Biol 3:a001438

Spaepen S, Vanderleyden J, Remans R (2007) Indole-3-acetic acid in microbial and microorganism-plant signaling. FEMS Microbiol Rev 31:425-448

Tamura K, Stecher G, Peterson D, Filipski A, Kumar S (2013) MEGA6: molecular evolutionary genetics analysis version 6.0. Mol Biol Evol 30:2725-2729

Vacheron J, Desbrosses G, Bouffaund M-L, Touraine B, MoënneLoccoz Y, Muller D, Legendre L, Wisnewski-Dyé F, PrigentCombared C (2013) Plant growth-promoting rhizobacteria and root system functioning. Front Plant Sci 4:1-19
Van Veen JA, van Overbeek LS, van Elsas JD (1997) Fate and activity of microorganisms introduced into soil. Microbiol Mol Biol Rev 61:121-135

Verma JP, Yadav J, Tiwari KN, Lavakush Singh V (2010) Impact of plant growth promoting rhizobacteria on crop production. Int $\mathrm{J}$ Agric Res 5:954-983

Wahyudi AT, Astuti RP, Widyawati A, Meryandini A, Nawangsih AA (2011) Characterization of Bacillus sp. strains isolated from rhizosphere of soybean plants for their use as potential plant growth for promoting rhizobacteria. J Microbiol Antimicrob 3:34-40

Wissuwa M, Mazzola M, Picard C (2009) Novel approaches in plant breeding for rhizosphere-related traits. Plant Soil 321:409-430

Yamamoto S, Ksai H, Arnold DL, Jackson RW, Vivian A, Harayama S (2000) Phylogeny of the genus Pseudomonas:intrageneric structure reconstructed from the nucleotide sequences of $g y r B$ and rpoD genes. Microbiology 146:2385-2394

Young JM, Park DC, Weir BS (2004) Diversity of 16S rDNA sequences of Rhizobium spp. implications for species determinations. FEMS Microbiol Lett 238:125-131

Zamioudis Ch, Mastranesti P, Dhonukshe P, Blilou I, Pieterse CMJ (2013) Unraveling root developmental programs initiated by beneficial Pseudomonas spp. bacteria. Plant Physiol 162:304-318

Zhang H, Kim MS, Krishnamachari V, Payton P, Sun Y, Grimson M, Farag MA, Ryu CM, Allen R, Melo IS, Paré PW (2007) Rhizobacterial volatile emissions regulate auxin homeostasis and cell expansion in Arabidopsis. Planta 226:839-851 